Article

\title{
Changes in Chemical Properties of Banana Pseudostem, Mushroom Media Waste, and Chicken Manure through the Co-Composting Process
}

\author{
Mahammad Shariful Islam ${ }^{1,2} \mathbb{D}$, Susilawati Kasim ${ }^{1, *}$, Khairul Md. Alam 2,3,4 ${ }^{\mathbb{D}}$, Adibah Mohd Amin ${ }^{1}$, \\ Tan Geok Hun ${ }^{5}$ and Mohammad Amdadul Haque ${ }^{2,6}$ (D) \\ 1 Department of Land Management, Faculty of Agriculture, Universiti Putra Malaysia, \\ Serdang 43400, Malaysia; sharifultasim@gmail.com (M.S.I.); adibahamin@upm.edu.my (A.M.A.) \\ 2 Bangladesh Agricultural Research Institute, Gazipur 1701, Bangladesh; khairul.krishi@gmail.com (K.M.A.); \\ amdad80@gmail.com (M.A.H.) \\ 3 Centre for Sustainable Farming Systems, Future Food Institute, Murdoch University, \\ Perth, WA 6150, Australia \\ 4 Bangladesh Agricultural Research Council, Dhaka 1215, Bangladesh \\ 5 Department of Agriculture Technology, Faculty of Agriculture, Universiti Putra Malaysia, \\ Serdang 43400, Malaysia; geok_hun@upm.edu.my \\ 6 Department of Crop Science, Faculty of Agriculture, Universiti Putra Malaysia, Serdang 43400, Malaysia \\ * Correspondence: susilawati@upm.edu.my; Tel.: +60-3976-948-62
}

check for

updates

Citation: Islam, M.S.; Kasim, S.;

Alam, K.M..; Amin, A.M.; Geok Hun,

T.; Haque, M.A. Changes in Chemical

Properties of Banana Pseudostem,

Mushroom Media Waste, and

Chicken Manure through the

Co-Composting Process.

Sustainability 2021, 13, 8458.

https://doi.org/10.3390/su13158458

Academic Editors: Chunjiang An

Received: 5 May 2021

Accepted: 7 July 2021

Published: 28 July 2021

Publisher's Note: MDPI stays neutral with regard to jurisdictional claims in published maps and institutional affiliations.

Copyright: (c) 2021 by the authors. Licensee MDPI, Basel, Switzerland. This article is an open access article distributed under the terms and conditions of the Creative Commons Attribution (CC BY) license (https:// creativecommons.org/licenses/by/ $4.0 /)$.
Abstract: Co-composting is an effective approach to biowaste management. The co-composting potential of banana pseudostem (BPS) and mushroom media waste (MMW) with chicken manure (CM) has not been explored, let alone their suitable ratios of co-composting being determined. Meanwhile, the imbalance ratios of the feedstocks used in the process severely restrict the physicochemical properties and quality of the finished product. For this reason, six different ratios of BPS, MMW, and CM, viz. 1:1:1, 1:2:1, 1:3:1, 2:1:1, 2:2:1, and 2:3:1, respectively $\left(\mathrm{T}_{1}-\mathrm{T}_{6}\right)$, were composted together in aerobic conditions to identify the suitable ratio by evaluating the changes in the physicochemical properties in the composting process. According to the ratio of treatments, the feedstocks were mixed on fresh weight basis. The turning process of co-composting piles was repeated at seven-day intervals to maintain the uniform aeration throughout the composting period. The piles having BPS, MMW, and $\mathrm{CM}$ at ratios of 1:2:1, 1:3:1, and 2:3:1, respectively, demonstrated a longer thermophilic phase, indicating more complete decomposition and earlier maturity compared to piles with higher amount of BPS. Of the ratios, BPS:MMW:CM at 1:2:1 ratio $\left(\mathrm{T}_{2}\right)$ resulted in the highest total nitrogen $(1.53 \%)$, lowest C:N ratio (12.4), organic matter loss (54.5\%), and increased CEC (41.3 cmol $/ \mathrm{kg})$. The highest germination index $(129 \%)$ was also recorded in the $\mathrm{T}_{2}$ compost, indicating that it was toxic-free and safe for seed germination. The nutrient-rich compost with high alkaline $\mathrm{pH}(\geq 10)$ can effectively ameliorate soils of an acidic nature, for example, the acidity of Ultisols and Oxisols.

Keywords: banana pseudostem; mushroom media waste; chicken manure; chemical properties; co-compost

\section{Introduction}

Agricultural waste can potentially be recycled through composting processes (composting and co-composting) that convert it into useful resources for plant nutrition and soil health (through adding humus-like materials) [1]. One of the key considerations of composting and co-composting is the sources and types of organic materials used. Mainly, co-composting involves mixing nitrogen-rich organic wastes such as nutshells, sewage sludge, and animal manure with carbon-rich organic wastes (bulking agent) such as saw-dust, crop residue, biochar [2,3], and mushroom spent substrate [4]. On the other hand, banana pseudostem has huge potential as a co-composting material [5]. The global 
production of pseudostem currently amounts to approximately 336 million tonnes [6] at the rate of $60-70$ tonnes $\mathrm{ha}^{-1}$ as post-harvest waste. It mostly remains unused and is simply creating more pollution. Yet, it can be a vital source of nutrients that will regulate and assist plant growth [7]. Similarly, mushroom production has risen worldwide resulting in an estimated 53 million tons of mushroom media waste (MMW) $(1 \mathrm{~kg}$ mushroom is produced from $5 \mathrm{~kg}$ mushroom media substrate). Carbon (C)-rich mushroom media waste has immense promise for composting [8] because of its large surface area and contains carbohydrates, protein, fat, and many kinds of enzymes as well as fungus mycelium and residual nutrients $[9,10]$. The demand for livestock and the production of poultry has increased significantly with the rising human population, which has resulted in producing large quantities of manure [11,12]. With comparatively high nitrogen $(\mathrm{N})$, co-composting with chicken manure helps turn various organic solid wastes into suitable composts by controlling the activity of microorganisms [11].

Silva and Bras [13] showed that chicken manure is usually rich in $\mathrm{N}$ but poor in C, leading to a low C:N ratio, which restricts the composting process. Apart from these, chicken manure enhanced the microbial growth and activity for efficient composting by shortening the composting period [10]. Being rich in C, the addition of mushroom media waste can act as an adsorbent of readily available $\mathrm{N}$ and allows the microbial population to multiply and immobilize $\mathrm{N}$ present in chicken manure. Conversely, banana pseudostem may help check $\mathrm{N}$ loss through the formation of struvite with ammonium- $\mathrm{N}\left(\mathrm{NH}_{4}{ }^{+}-\mathrm{N}\right)$. Moreover, 80-90\% water by weight [14] may ensure the best possible moisture content in the process. Considering the above individual properties, these materials have the potential to produce quality compost.

Previous research has studied the quality of composts produced by the co-composting method and generally proved that the method of composting, combinations between them, and the ratio at which the co-composting materials are used, determine the quality of the final compost. Accordingly, the rate of degradation and mineralization process was enhanced through the co-composting of banana peels with poultry manure [15]. Soto-Paz et al. [16] evaluated the potential of biowaste and sugarcane filter cake for composting. They recorded that the composting of biowaste and sugarcane filter cake at the 4:1 ratio showed faster maturity and stability of the final compost. Similarly, the composting of poultry manure, cellulosic sludge, and wood chips together showed faster decomposition with the increment of nutrients and organic matter $(\mathrm{OM})$, while also maintaining the $\mathrm{C}: \mathrm{N}$ ratio below 20 as quality compost [13]. Meunchang et al. [17] observed the rapid loss of OM from the composting of (2:1) sugarcane filter cake with its bagasse. Moreover, the co-composting of $25 \%$ wood chips and $25 \%$ green waste resulted in a quality compost with optimum $\mathrm{pH}$, electrical conductivity (EC), cation exchange capacity (CEC), and germination index (GI $>80 \%$ ) value [18]. As the C: $\mathrm{N}$ ratio of chicken manure is comparatively low, it tends to emit more ammonia than from other organic sources [19]. To deal with this problem, other materials can be used at different ratios to suppress the emissions by adjusting the material's C:N ratio. Studying the effects of initial mixtures on the characteristics of organic matter in composts, Francou et al. [20] found little stabilization of organic matter during composting of green wastes with their large lignin content. Chicken manure compost with $42.5 \%(w / w)$ bark in the feedstock had the best quality as a soil improver in terms of organic matter content, C:P ratio, C:N ratio, and stability [21].

Likewise, research on the composting of animal manure with bulking materials such as cereal crop residues [22,23], cotton crop waste [24], and wood shavings, leaves, and sawdust $[25,26]$ have been undertaken throughout the world. Several analyses have explored co-composting of chicken manure with farmyard manure, pig manure, animal dung, garden waste, green waste material, sawdust, animal farm litter, and bedding material [27-30]. Kalemelawa et al. [15] evaluated the aerobic and anaerobic composting of banana peels treated with inoculums. He et al. [29] used pig manure, wheat straw, and rice straw biochar in composting. Kumar et al. [30] executed simultaneous composting of sugarcane waste with mushroom substrate and wheat straw to improve compost quality. 
Similarly, Czekała et al. [31] also investigated biochar with poultry manure and wheat straw in the aerobic co-composting process in their study.

However, not enough research has been published on co-composting using banana wastes and the subsequent physicochemical changes that occur during composting. Most research has been done in the laboratory, but here, the nutrient parameters are limited. Such studies' results did not truly reflect the utility of crop demand in agriculture. Banana pseudostem is a highly alkaline organic waste that contains cellulose and lignin with $75-85 \%$ moisture [32]. The addition of excessive moisture and inappropriate ratios of a mixture may lead to delaying the process through the poor window, which does not favor microbe and quality compost [33].

The inherent moisture in the banana pseudostem along with a suitable ratio of MMW and frequent turning would create a congenial condition for faster decomposition in the process. Composting of these materials together may alleviate the negative impacts of individual waste on crops and might turn the compost into a balanced organic fertilizer able to synchronize the release of nutrients with the demand of crops in acidic soil. To the best of our knowledge, no research has investigated the decomposition of banana pseudostem and mushroom media waste with chicken manure to utilize them as organic fertilizer through co-composting. Therefore, in order to make effective compost, the ratio of the substrate mixture must first be determined. The objective of the study was to identify the suitable ratio of banana pseudostem to mushroom media waste in co-composting with chicken manure.

\section{Materials and Methods}

\subsection{Materials Collection, Preparation, and Pile Management}

The required amounts of semi-humified chicken manure (CM), mushroom media waste (MMW), and banana pseudostem (BPS) samples were collected from QL Ansan Poultry Farm Sdn Bhd, Rawang ( $3^{\circ} 27^{\prime} 31.97^{\prime \prime} \mathrm{N}$ and $101^{\circ} 35^{\prime} 21.23^{\prime \prime}$ E), Nas Agro Farm, Sepang $\left(2^{\circ} 50^{\prime} 52.64^{\prime \prime} \mathrm{N}\right.$ and $\left.101^{\circ} 44^{\prime} 38.23^{\prime \prime} \mathrm{E}\right)$, and Banting, $\left(2^{\circ} 48^{\prime} 16.1^{\prime \prime} \mathrm{N}\right.$ and $101^{\circ} 30^{\prime} 10.99^{\prime \prime}$ E), Malaysia, respectively. The collected CM and MMW were properly cleaned, sieved, and preserved separately in an open polyshade house at ambient temperature $\left(25^{\circ} \mathrm{C}\right.$ to $\left.28^{\circ} \mathrm{C}\right)$. The day before composting, fresh banana pseudostems were chopped down into desirable sizes then crushed with a $14 \mathrm{HP}$, woodchipper machine (Model: Ohashi-GS122GB, Obashi Ecological technology, Sakimura Chiyoda Kanzaki Saga, Japan). Banana pseudostem sap was collected through the outlet pipe during the crushing of banana pseudostem. The sap was subjected to the addition of an extra $250 \mathrm{~g}$ urea and maintained moisture (at 60-70\%) in the composting piles. In each pile, the $250 \mathrm{~g}$ of urea was evenly sprinkled in each layer of feedstock mixtures with pseudostem sap and water. It was uniformly spattered in different layers in the final mixture during pile preparation to promote decomposition. The piles were protected with a rainproof, non-transparent and thick plastic canvas from any unexpected weather disturbance. Turning and mixing (manually by shovel) were done weekly to allow uniform airflow throughout the composting period. The initial chemical properties of individual materials were measured prior to the co-composting process (Table 1).

Table 1. Physicochemical characteristics of the raw materials used in the co-composting process.

\begin{tabular}{cccc}
\hline Properties & Banana Pseudostem (BPS) & Chicken Manure (CK) & Mushroom Media Waste (MMW) \\
\hline Moisture (\%) & $59.23 \pm 4.74$ & $14.52 \pm 0.59$ & $28.50 \pm 0.35$ \\
pH & $10.41 \pm 0.18$ & $9.53 \pm 0.33$ & $6.19 \pm 0.13$ \\
EC (dSm $\left.{ }^{-1}\right)$ & $4.74 \pm 0.14$ & $4.66 \pm 0.13$ & $0.70 \pm 0.02$ \\
Total C $\%)$ & $35.14 \pm 1.23$ & $23.57 \pm 1.08$ & $40.12 \pm 1.42$ \\
OM (\%) & $77.78 \pm 2.10$ & $50.0 \pm 1.95$ & $94.94 \pm 3.03$ \\
C:N ratio & $73.20 \pm 1.56$ & $8.93 \pm 0.26$ & $16.05 \pm 0.51$ \\
Total N (\%) & $0.48 \pm 0.07$ & $2.64 \pm 0.06$ & $2.50 \pm 0.06$ \\
CEC (cmol (+)/ $\left.\mathrm{kg}^{-1}\right)$ & $30.00 \pm 1.25$ & $24.85 \pm 1.14$ & $24.35 \pm 0.88$ \\
\hline
\end{tabular}


Table 1. Cont.

\begin{tabular}{cccc}
\hline Properties & Banana Pseudostem (BPS) & Chicken Manure (CK) & Mushroom Media Waste (MMW) \\
\hline Potassium $\left(\mathrm{K}, \mathrm{g} \mathrm{kg}^{-1}\right)$ & $14.06 \pm 0.57$ & $12.59 \pm 0.47$ & $3.24 \pm 0.16$ \\
Calcium $\left(\mathrm{Ca}, \mathrm{g} \mathrm{kg}^{-1}\right)$ & $9.60 \pm 0.35$ & $12.36 \pm 0.43$ & $12.27 \pm 0.55$ \\
Magnesium $\left({\left.\mathrm{Mg}, \mathrm{g} \mathrm{kg}^{-1}\right)}^{\text {Sodium }\left(\mathrm{Na}, \mathrm{g} \mathrm{kg}^{-1}\right)}\right.$ & $2.52 \pm 0.09$ & $3.60 \pm 0.14$ & $2.41 \pm 0.08$ \\
Total P $\left(\mathrm{g} \mathrm{kg}^{-1}\right)$ & $0.87 \pm 0.04$ & $2.48 \pm 0.09$ & $0.55 \pm 0.04$ \\
Copper $\left(\mathrm{mg} \mathrm{kg}^{-1}\right)$ & $7.40 \pm 0.31$ & $6.20 \pm 0.24$ & $8.02 \pm 0.37$ \\
Manganese $\left(\mathrm{Mn}, \mathrm{mg} \mathrm{kg}^{-1}\right)$ & $35.40 \pm 1.70$ & $41.60 \pm 1.66$ & $14.10 \pm 0.59$ \\
Zinc $\left(\mathrm{Zn}, \mathrm{mg} \mathrm{kg}^{-1}\right)$ & $160.3 \pm 6.25$ & $32.72 \pm 0.98$ & $101.2 \pm 5.06$ \\
\hline
\end{tabular}

Mean \pm Standard deviation are the average of three replicated samples (dry basis).

\subsection{Research Design}

The raw materials of BPS, MMW, and CM were mixed manually with six ratios, viz., $\mathrm{T}_{1}=1: 1: 1, \mathrm{~T}_{2}=1: 2: 1, \mathrm{~T}_{3}=1: 3: 1, \mathrm{~T}_{4}=2: 1: 1, \mathrm{~T}_{5}=2: 2: 1$, and $\mathrm{T}_{6}=2: 3: 1$, respectively, before the compost piles were prepared for each treatment. The compost pile was $2 \mathrm{~m}$ length $\times 1.2 \mathrm{~m}$ width $\times 1.0 \mathrm{~m}$ height in size volume. According to the treatment ratio, each compost pile received in total $500 \mathrm{~kg}$ of three feed stocks as fresh weight basis where the initial moistures of CM, MMW, and BPS were $14.5 \%, 8.5 \%$, and $59.2 \%$, respectively. Each pile had two replications and samples were replicated three times following Randomized Complete Block design.

\subsection{Collection and Preparation of Compost Samples for Physicochemical Analysis}

A $300 \mathrm{~g}$ of bulk sample was randomly collected from different places (6) of two compost pile in each round of turning and mixture and divided into two parts. The first part of these samples was air-dried and passed through the 0.25- and 0.1-mm sieves and sample repeated three times for physicochemical analysis. Each sub-sample was considered as replication. The second part of the compost samples was immediately preserved in a refrigerator at $4-5{ }^{\circ} \mathrm{C}$ for seed germination test.

\subsection{Monitoring of Temperature Profile $\left({ }^{\circ} \mathrm{C}\right)$ and Moisture in the Composting Process}

The temperature was recorded daily in the morning (before $8 \mathrm{am}$ ) and evening (after $5 \mathrm{pm}$ ) from the three places of the piles (central, mid-peripheral, and lower-peripheral positions) by portable Mercury thermometer (Alchl Thrmter, Labworld, India). In that case, half portion of the thermometer was dipped into the pile from the top centre while the whole portion was dipped from the mid and lower-peripheral position to get the actual average temperature [16]. The ambient temperature was also recorded by the same thermometer at the same times. The daily six readings per compost pile recorded in the morning (3) and evening (3) were averaged.The compost moisture was measured by the gravimetric method where sample was dried at $105^{\circ} \mathrm{C}$ until reaching the constant weight [34]. The moisture $(\%)$ was calculated following the equation: moisture $(\%)=\frac{\left(\mathrm{W}_{1}-\mathrm{W}_{2}\right)}{\mathrm{W}_{1}} \times 100$, where weight of compost before oven drying $\left(\mathrm{W}_{1}\right)$ and weight of compost after oven drying $\left(\mathrm{W}_{2}\right)$.

\subsection{Chemical Analysis of the Compost Samples}

The $\mathrm{pH}$ was measured from the compost samples by a digital $\mathrm{pH}$ meter $(\mathrm{HI} 2211 \mathrm{pH}$ meter, Hanna instrument, Woonsocket, RI, USA) at the ratio of 1:10 $(w / v)$ water-soluble extract, whereas 1:20 (w/v) ratio of the sample with water was used to determine EC by digital EC meter (Hanna 2300) as described by Gaind [35]. The total C, N, and sulfur (S) were determined by Leco TruMac CNS analyzer. The C:N ratio was calculated from the total $\mathrm{C}$ and total $\mathrm{N}$ values. The TOC and OM contents of compost samples were estimated by loss on ignition method [36]). The CEC was determined by the ammonium acetate ( $\mathrm{pH}$ 7.0) leaching method [37]. Inorganic $\mathrm{N}$ was determined using the method of Keeney and Nelson [38]. The total contents of $\mathrm{K}, \mathrm{Ca}, \mathrm{Mg}, \mathrm{Na}, \mathrm{Mn}, \mathrm{Cu}$, and $\mathrm{Zn}$ were determined by atomic absorption spectrophotometer (A Analyst 800, PerkinElmer Corporation, Norwalk, 
CT, USA) followed by dry ashing method, based on Cottenie [37], and the amount of P was determined by auto-analyzer (Yellow method) from the same sample.

\subsection{Compost Toxicity Test}

The germination index of radish seeds was tested via the water extraction procedure as suggested by Guo et al. [39]. Briefly, the compost samples and deionized water at the ratio of 1:10 $(w / v)$ was centrifuged for $15 \mathrm{~min}$ at $4000 \mathrm{rpm}$ and filtered through $0.45 \mu \mathrm{m}$ filter paper. A $5 \mathrm{~mL}$ of filtrate was pipetted in to $20 \mathrm{~mm} \times 100 \mathrm{~mm}$ triplicate sterilizer Petri dish after placing double filter papers on it. Thirty randomly selected radish seeds were placed evenly on filter paper, sealed, and kept on the Petri dish in a dark place for $72 \mathrm{~h}$ at room temperature. The total number of germinated seeds were counted in the Petri dish and recorded as a percentage. Root length of the germinated seeds was measured by image J. software [40]. The germination index (GI) was calculated by the following equation:

$$
\mathrm{GI}(\%)=[\mathrm{SG}(\%) \text { of treatment } \times \mathrm{RL}] /[\mathrm{SG} \text { of } \operatorname{control}(\%) \times \mathrm{RL} \text { of control }] \times 100,
$$

where SG = seed germination of treatments, $R L=$ root length of the treatments $(\mathrm{cm})$.

\subsection{Statistical Analysis}

Data were subjected to analysis by PROC ANOVA in the RCBD design (SAS, 9.4). The treatment means were compared by protected Least Significant Difference Test (LSD) at the $5 \%$ probability level [41].

\section{Results}

\subsection{Monitoring Temperature Profile during the Composting Period}

Irrespective of treatments, the temperature rise from the first day and reached the peak at $4-5$ days. The use of BPS, MMW, and CM at different ratios had varied temperatures over the co-composting period (Figure 1a,b). The temperature reaching the thermophilic phase for piles $\mathrm{T}_{2}$ (1:2:1 BPS:MMW:CM), $\mathrm{T}_{3}$ (1:3:1 BPS:MMW:CM), and $\mathrm{T}_{6}$ (2:3:1 BPS:MMW:CM) lasted up to 29 days, while for $\mathrm{T}_{1}$ pile (1:1:1 BPS:MMW:CM), the phase lasted for 4-19 days (Figure $1 \mathrm{a}, \mathrm{b})$. However, $\mathrm{T}_{5}$ pile (2:2:1 BPS:MMW:CM) took 13-19 days to reach the same phase $\left(52.7^{\circ} \mathrm{C}\right.$ to $\left.55.0^{\circ} \mathrm{C}\right)$. Elsewhere, the temperature ranged from $45.4{ }^{\circ} \mathrm{C}$ to $48.8^{\circ} \mathrm{C}$ in $\mathrm{T}_{4}$ pile (2:1:1 BPS:MMW:CM) and it consistently remained below the thermophilic stage $\left(<50{ }^{\circ} \mathrm{C}\right)$ throughout the composting period. After a longer mesophilic phase $\left(40-50{ }^{\circ} \mathrm{C}\right)$, the temperature in all the piles (except $\mathrm{T}_{4}$ pile) started falling and reached cooling stage $\left(<40{ }^{\circ} \mathrm{C}\right)$ after $58,49,52,58$, and 55 days, respectively.

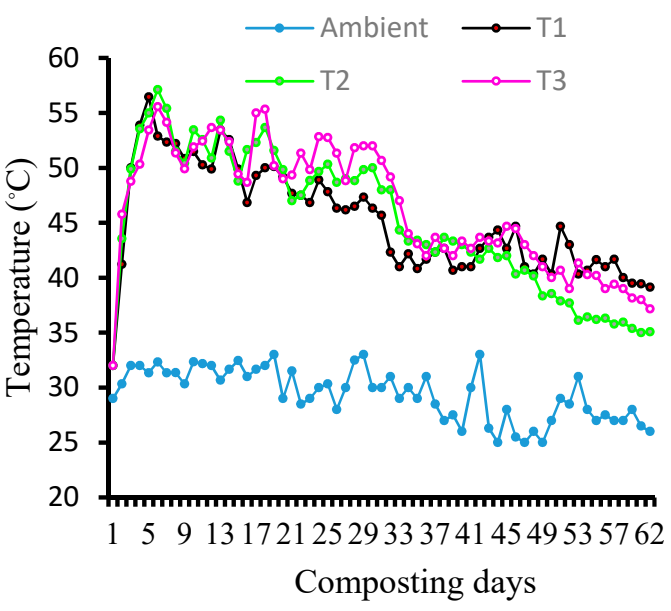

(a)

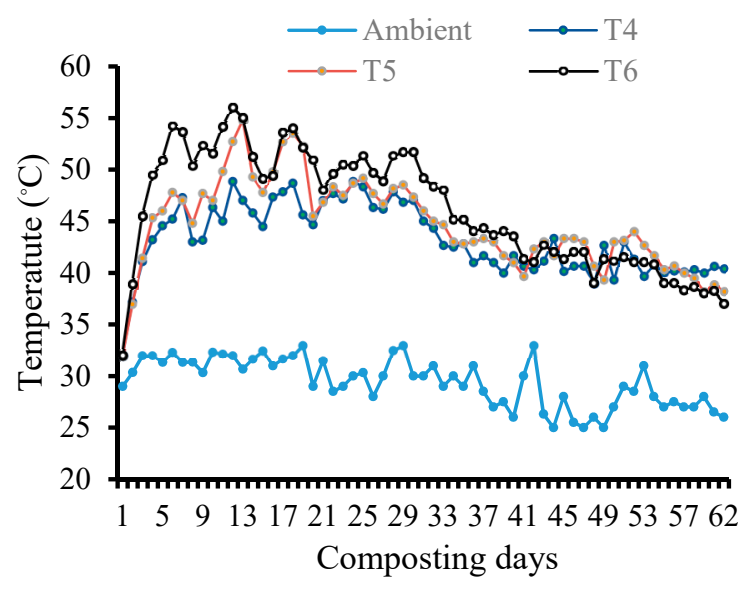

(b)

Figure 1. Temperature during the composting as affected by $\mathrm{T}_{1}-\mathrm{T}_{3}$ treatments (a); Temperature during the composting as affected by $\mathrm{T}_{4}-\mathrm{T}_{6}$ treatments (b). 


\subsection{Changes in $\mathrm{pH}$ and $\mathrm{EC}$ during the Co-Composting}

During the composting period, the $\mathrm{pH}$ levels in the piles were consistently varied. An increase in the $\mathrm{pH}$ and EC levels was observed in each co-compost pile (treatment) (Figures 2 and 3). In the primary stage of composting, $\mathrm{pH}$ values revealed a slight decline or remained unchanged up to 7 days in the $\mathrm{T}_{2}$ pile having increased the amount of MMW followed by the $T_{3}$ pile, where the $T_{4}$ pile, with a larger amount of BPS, showed a sharp increase in $\mathrm{pH}$ value. In the secondary stage, the $\mathrm{pH}$ increased gradually up to the final compost. Generally, $\mathrm{pH}$ varied from 7.69-8.74 in the initial stage and from 10.0-10.6 in the final stage. However, in the final compost, the lowest $\mathrm{pH}$ level (10.0) was recorded in the $T_{2}$ pile having an increased amount of MMW (1:2:1 of banana pseudostem, mushroom media waste, and chicken manure) followed by the $T_{3}$ (1:3:1 BPS:MMW:CM) pile, while the highest $\mathrm{pH}$ (10.6) was recorded in the $\mathrm{T}_{4}$ (2:1:1) pile where BPS was used in an increased ratio. The EC increase was accompanied by the rising temperature in the co-compost under process (Figure 1a,b). In the final compost, EC ranged from 2.38 to $3.71 \mathrm{dS} \mathrm{m}^{-1}$ in the compost piles, while the $T_{2}$ pile mixed with the increased amount of MMW displayed the lowest EC value $\left(2.38 \mathrm{dS} \mathrm{m}^{-1}\right)$, followed by $\mathrm{T}_{3}\left(2.68 \mathrm{dS} \mathrm{m}^{-1}\right)$ treatment. In the last stage of the co-composting process, the highest $\mathrm{EC}\left(3.71 \mathrm{dS} \mathrm{m}^{-1}\right)$ was recorded in the $\mathrm{T}_{4}$ pile, which was mixed with increased BPS substrate.

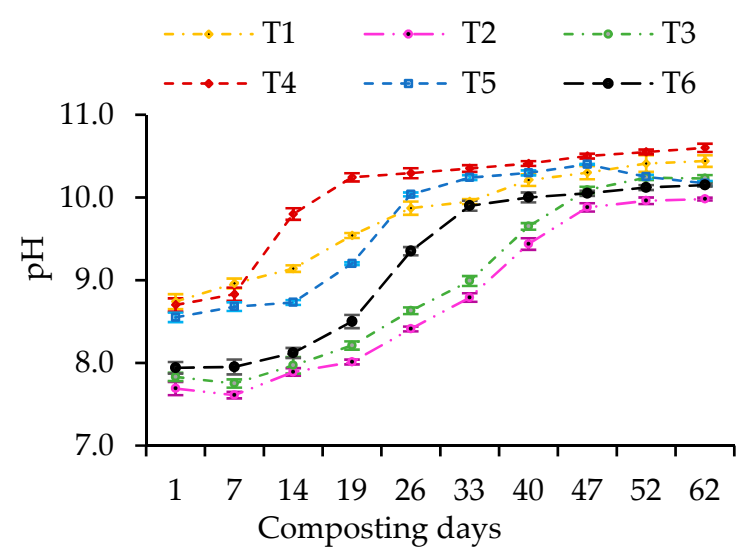

Figure 2. Changes of $\mathrm{pH}$ during the composting. Each marker point represents mean $(n=3)$, and the vertical bars indicate Standard Error of Means (S.E.M). Legends: BPS, MMW, and CM mixed at $\mathrm{T}_{1}=1: 1: 1, \mathrm{~T}_{2}=1: 2: 1, \mathrm{~T}_{3}=1: 3: 1, \mathrm{~T}_{4}=2: 1: 1, \mathrm{~T}_{5}=2: 2: 1$, and $\mathrm{T}_{6}=2: 3: 1$, respectively.

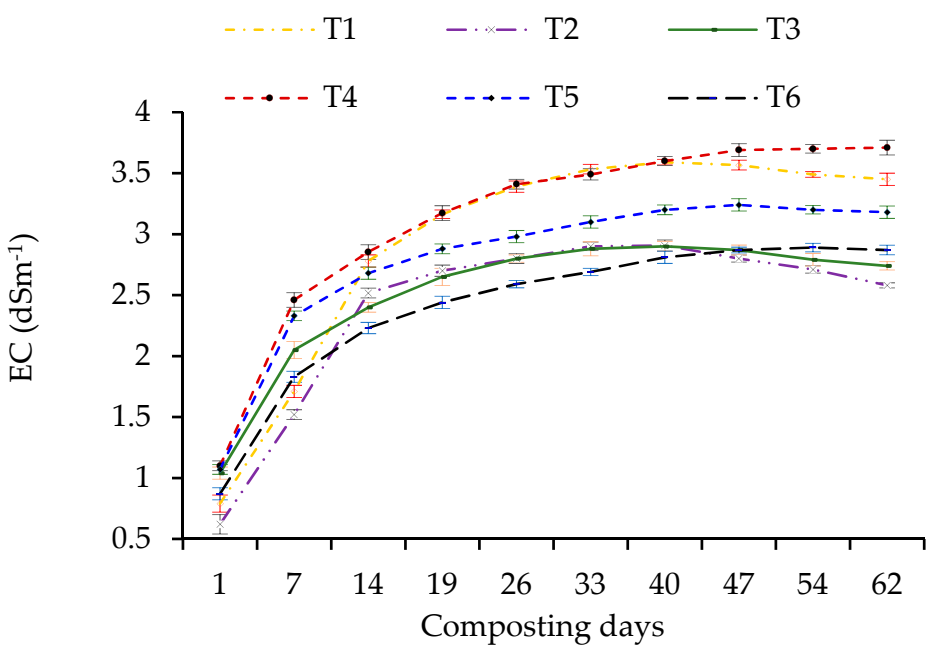

Figure 3. Changes of EC during the composting. Each marker point represents mean $(n=3)$, and the vertical bars indicate Standard Error of Means (S.E.M). Legends: BPS, MMW, and CM mixed at $\mathrm{T}_{1}=1: 1: 1, \mathrm{~T}_{2}=1: 2: 1, \mathrm{~T}_{3}=1: 3: 1, \mathrm{~T}_{4}=2: 1: 1, \mathrm{~T}_{5}=2: 2: 1$, and $\mathrm{T}_{6}=2: 3: 1$, respectively. 


\subsection{Organic Matter Degradation}

The mixing of BPS, MMW, and CM in different ratios significantly influenced the OM degradation in the process (Figure 4). Throughout the composting period, the rapid reduction of OM was recorded in the $\mathrm{T}_{2}$ pile with 1:2:1 BPS:MMW:CM (79.4\% to $\left.36.13 \%\right)$, which was followed by the $T_{3}$ pile, while the slowest decomposition was recorded in the $\mathrm{T}_{4}$ pile having a larger amount of BPS used (2:1:1 BPS:MMW:CM). The decomposition of the initial substrate biomass fell from $66.8 \%$ to $49.29 \%$ in the $\mathrm{T}_{4}$ pile. However, the highest $(54.5 \%)$ relative loss of $\mathrm{OM}$ was calculated from the initial to the final stage of the $\mathrm{T}_{2}$ pile of co-compost with double the MMW used compared to the $\mathrm{T}_{4}$ pile.

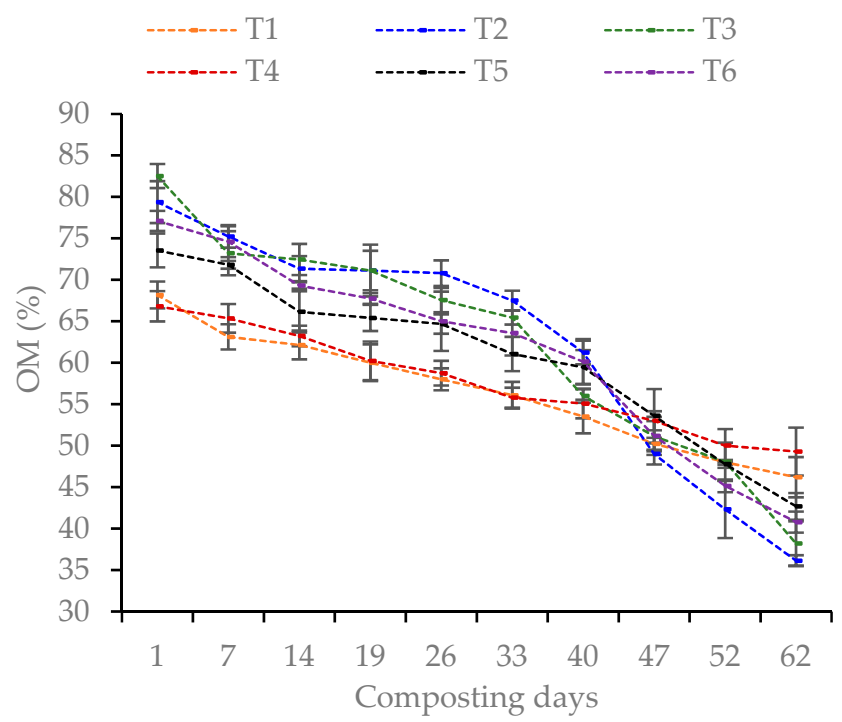

Figure 4. Degradation of organic matter during the composting period. The vertical bars indicate Standard Error of Means (S.E.M). Legends: BPS, MMW, and CM mixed at $\mathrm{T}_{1}=1: 1: 1, \mathrm{~T}_{2}=1: 2: 1$, $\mathrm{T}_{3}=1: 3: 1, \mathrm{~T}_{4}=2: 1: 1, \mathrm{~T}_{5}=2: 2: 1$, and $\mathrm{T}_{6}=2: 3: 1$, respectively.

\subsection{Changes of Total $\mathrm{N}, \mathrm{NH}_{4}-\mathrm{N}$, and $\mathrm{NO}_{3}-\mathrm{N}$}

Changes of $\mathrm{N}$ were influenced by different ratios of feedstocks used in co-composting. The highest total $\mathrm{N}$ was recorded in $\mathrm{T}_{2}$ having 1:2:1 of BPS, MMW, and CM (1.53\%) along with $\mathrm{T}_{5}$ having 2:2:1 of BPS, MMW, and CM $(1.48 \%)$ piles, while the lowest $\mathrm{N}(1.10 \%)$ was recorded in the $\mathrm{T}_{4}$ pile (2:2:1 BPS:MMW:CM) (Table 2). In all piles, the total $\mathrm{N}$ loss varied from $11.1 \%$ to $23.6 \%$ from the initial to the end of the composting, which was recorded in the $\mathrm{T}_{2}$ and $\mathrm{T}_{1}$ piles with an equal amount of feedstocks, respectively. $\mathrm{NH}_{4}-\mathrm{N}$ ranged from $452-738 \mathrm{mg} \mathrm{kg}^{-1}$ in the first two weeks and decreased gradually to $120-179 \mathrm{mg} \mathrm{kg}^{-1}$ at the end of composting (Figure 5). However, $\mathrm{T}_{2}$, having a higher amount of MMW, had the largest amount of $\mathrm{NH}_{4}-\mathrm{N}\left(179 \mathrm{mg} \mathrm{kg}^{-1}\right)$ while the pile having higher BPS $\left(\mathrm{T}_{4}\right.$ pile) had the lowest $\left(120 \mathrm{mg} \mathrm{kg}^{-1}\right)$ at the final stage (Figure 5). The trend of $\mathrm{NO}_{3}-\mathrm{N}$ increased with the decline of $\mathrm{NH}_{4}-\mathrm{N}$ in all compost piles, and finally, significantly higher values of $\mathrm{NO}_{3}-\mathrm{N}$ were recorded in the $T_{2}\left(51.9 \mathrm{mg} \mathrm{kg}^{-1}\right)$ pile, followed by the $T_{3}$ pile $\left(48.5 \mathrm{mg} \mathrm{kg}^{-1}\right)$, and the lowest $\left(35.55 \mathrm{mg} \mathrm{kg}^{-1}\right.$ ) in the $\mathrm{T}_{4}$ pile (Figure 6). 
Table 2. Changes of moisture, C:N ratio, total N, and cation exchange capacity of different compost by co-composting.

\begin{tabular}{cccccccc}
\hline Parameters & Time & $\mathbf{T}_{\mathbf{1}}$ & $\mathbf{T}_{\mathbf{2}}$ & $\mathbf{T}_{\mathbf{3}}$ & $\mathbf{T}_{\mathbf{4}}$ & $\mathbf{T}_{\mathbf{5}}$ & $\mathbf{T}_{\mathbf{6}}$ \\
\hline \multirow{2}{*}{ Moisture content (\%) } & Initial & $72.12 \pm 2.35 \mathrm{ab}$ & $68.52 \pm 1.96 \mathrm{~b}$ & $70.6 \pm 1.73 \mathrm{ab}$ & $79.32 \pm 2.91 \mathrm{a}$ & $75.1 \pm 1.53 \mathrm{ab}$ & $73.39 \pm 1.19 \mathrm{ab}$ \\
& Final & $45.24 \pm 1.10 \mathrm{~b}$ & $38.55 \pm 0.94 \mathrm{~d}$ & $36.25 \pm 0.74 \mathrm{~d}$ & $50.10 \pm 1.43 \mathrm{a}$ & $43.41 \pm 0.71 \mathrm{bc}$ & $40.21 \pm 0.70 \mathrm{~cd}$ \\
\multirow{2}{*}{ Total Organic C (\%) } & Initial & $35.25 \pm 1.00 \mathrm{ab}$ & $40.96 \pm 1.01 \mathrm{a}$ & $42.56 \pm 0.97 \mathrm{a}$ & $34.55 \pm 1.13 \mathrm{c}$ & $37.98 \pm 0.93 \mathrm{abc}$ & $39.80 \pm 1.13 \mathrm{ab}$ \\
& Final & $24.08 \pm 0.59 \mathrm{ab}$ & $18.90 \pm 0.55 \mathrm{~d}$ & $20.09 \pm 0.57 \mathrm{~cd}$ & $25.61 \pm 0.52 \mathrm{a}$ & $22.25 \pm 0.40 \mathrm{bc}$ & $21.28 \pm 0.69 \mathrm{~cd}$ \\
Total N (\%) & Initial & $1.91 \pm 0.04 \mathrm{a}$ & $1.70 \pm 0.03 \mathrm{~b}$ & $1.68 \pm 0.04 \mathrm{~b}$ & $1.42 \pm 0.03 \mathrm{c}$ & $1.76 \pm 0.04 \mathrm{ab}$ & $1.70 \pm 0.03 \mathrm{~b}$ \\
& Final & $1.46 \pm 0.03 \mathrm{a}$ & $1.53 \pm 0.04 \mathrm{a}$ & $1.45 \pm 0.04 \mathrm{a}$ & $1.10 \pm 0.02 \mathrm{~b}$ & $1.48 \pm 0.03 \mathrm{a}$ & $1.42 \pm 0.02 \mathrm{a}$ \\
C:N & Initial & $18.44 \pm 0.60 \mathrm{c}$ & $24.09 \pm 0.58 \mathrm{ab}$ & $25.33 \pm 0.82 \mathrm{a}$ & $24.33 \pm 0.39 \mathrm{ab}$ & $21.57 \pm 0.70 \mathrm{~b}$ & $23.14 \pm 0.42 \mathrm{ab}$ \\
& Final & $16.49 \pm 0.40 \mathrm{~b}$ & $12.35 \pm 0.25 \mathrm{~d}$ & $13.76 \pm 0.22 \mathrm{~cd}$ & $23.28 \pm 0.52 \mathrm{a}$ & $15.03 \pm 0.42 \mathrm{bc}$ & $14.98 \pm 0.30 \mathrm{bc}$ \\
& Initial & $24.85 \pm 0.81 \mathrm{ab}$ & $27.48 \pm 0.63 \mathrm{ab}$ & $27.77 \pm 0.56 \mathrm{a}$ & $24.00 \pm 0.81 \mathrm{~b}$ & $25.42 \pm 0.71 \mathrm{ab}$ & $25.21 \pm 0.90 \mathrm{ab}$ \\
CEC $\left(\mathrm{cmol} \mathrm{kg}^{-1}\right.$ ) & Final & $38.00 \pm 0.50 \mathrm{bc}$ & $41.28 \pm 0.98 \mathrm{a}$ & $40.14 \pm 0.90 \mathrm{a}$ & $32.14 \pm 0.55 \mathrm{c}$ & $38.50 \pm 0.68 \mathrm{abc}$ & $40.07 \pm 0.88 \mathrm{ab}$ \\
\hline
\end{tabular}

Here, compost piles, viz. $T_{1}=1: 1: 1, T_{2}=1: 2: 1, T_{3}=1: 3: 1, T_{4}=2: 1: 1, T_{5}=2: 2: 1$, and $T_{6}=2: 3: 1$, indicates mixture ratio of banana pseudostem (BPS), mushroom media waste (MMW), and chicken manure (CM) respectively. Mean \pm standard error within the row followed by the same letter are not statistically significant at $p \geq 0.05$ by LSD Test.

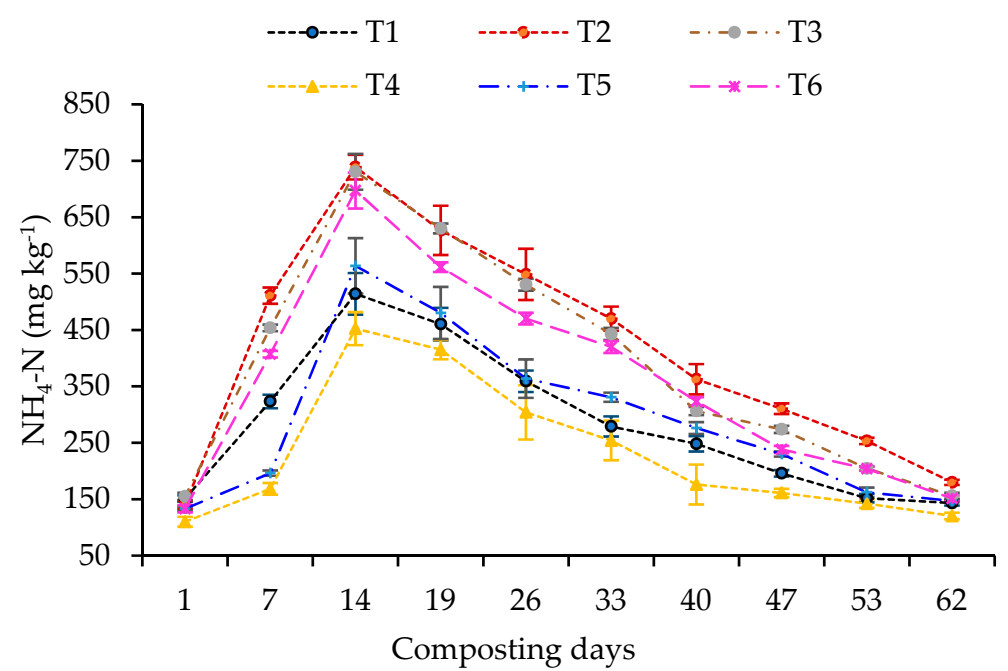

Figure 5. Changes of $\mathrm{NH}_{4}-\mathrm{N}$ during the composting. Each marker point represents mean $(n=3)$, and the vertical bars indicate Standard Error of Means (S.E.M). Legends: BPS, MMW, and CM mixed at $\mathrm{T}_{1}=1: 1: 1, \mathrm{~T}_{2}=1: 2: 1, \mathrm{~T}_{3}=1: 3: 1, \mathrm{~T}_{4}=2: 1: 1, \mathrm{~T}_{5}=2: 2: 1$, and $\mathrm{T}_{6}=2: 3: 1$, respectively.

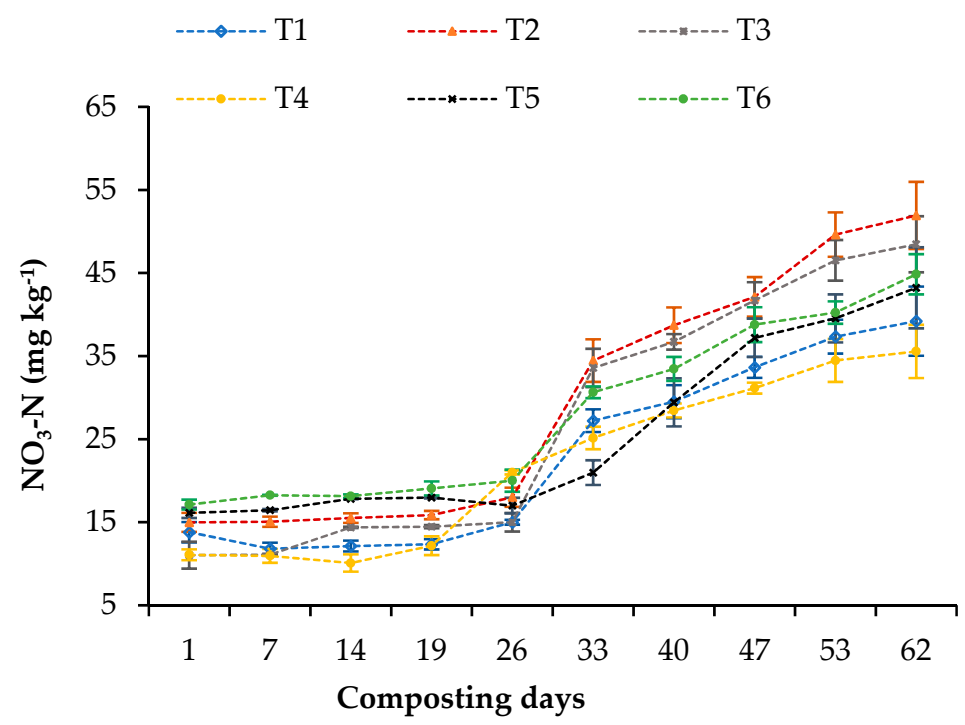

Figure 6. Changes of $\mathrm{NO}_{3}-\mathrm{N}$ during the composting. Each marker point represents mean $(n=3)$, and the vertical bars indicate Standard Error of Means (S.E.M). Legends: BPS, MMW, and CM mixed at $\mathrm{T}_{1}=1: 1: 1, \mathrm{~T}_{2}=1: 2: 1, \mathrm{~T}_{3}=1: 3: 1, \mathrm{~T}_{4}=2: 1: 1, \mathrm{~T}_{5}=2: 2: 1$, and $\mathrm{T}_{6}=2: 3: 1$, respectively. 


\subsection{Changes in Moisture}

Among the treatments, the moisture content, total $\mathrm{C}$, total $\mathrm{N}$, and the $\mathrm{C}: \mathrm{N}$ ratio fell from the initial to final stage whereas the CEC was increased significantly $(p \leq 0.05)$ (Table 2). The moisture content varied from $68.5 \%$ to $79.3 \%$ in the initial stage and $36.3 \%$ to $50.1 \%$ in the final stage. The minimum moisture $(36.3 \%)$ was observed in the final compost at $\mathrm{T}_{3}$ pile, which was statistically similar to the $\mathrm{T}_{2}(38.6 \%)$ pile, while the maximum moisture of $50.1 \%$ was recorded from $\mathrm{T}_{4}$ compost ( $50 \%$ banana pseudostem, $25 \%$ mushroom media waste, and $25 \%$ chicken manure).

\subsection{Changes in Total $C$}

A remarkable decrease in TOC was found from the beginning to the final compost and it ranged from $25.9-53.9 \%$ in the piles where $31.7 \%, 53.9 \%, 52.8 \%, 25.9 \%, 41.4 \%$, and $46.5 \%$ were recorded in the $\mathrm{T}_{1}, \mathrm{~T}_{2}, \mathrm{~T}_{3}, \mathrm{~T}_{4}, \mathrm{~T}_{5}$, and $\mathrm{T}_{6}$ piles, respectively. The highest reduction of $53.9 \%$ appeared in the $\mathrm{T}_{2}$ (1:2:1 ratio) pile and $25.9 \%$ in the $\mathrm{T}_{4}(2: 1: 1$ ratio) pile. Of the six compost mixtures, however, the lowest content $(18.9 \%)$ of organic $\mathrm{C}$ was recorded in $\mathrm{T}_{2}$, and the highest was $25.6 \%$ in $\mathrm{T}_{4}$, followed by the $\mathrm{T}_{1}(24.1 \%)$ co-compost pile.

\subsection{Changes in C:N Ratio}

All the compost samples had a C:N ratio below 20 except for $\mathrm{T}_{4}$ (23.3), while the lowest C: $N$ ratio (12.4) in $T_{2}$ was statistically identical to (1:3:1) the $T_{3}$ (13.8) pile at the end of composting (Table 2). Moreover, the $\mathrm{C}: \mathrm{N}$ ratio of the compost significantly decreased by $10.6 \%, 48.7 \%, 45.7 \%, 4.31 \%, 30.3 \%$, and $35.3 \%$ in the $\mathrm{T}_{1}-\mathrm{T}_{6}$ treatments, respectively. Among the treatments, the highest $\mathrm{C}: \mathrm{N}$ ratio decreased $(48.7 \%)$ in $\mathrm{T}_{2}$ and the lowest $(4.31 \%)$ was in $\mathrm{T}_{4}$ from initial to final compost.

\subsection{Changes in CEC}

The CEC for all treatments has shown a significant increase in the final compost (Table 2). The piles $\mathrm{T}_{2}$ (1:2:1 BPS:MMW:CM), $\mathrm{T}_{3}$ (1:3:1 BPS:MMW:CM), and $\mathrm{T}_{5}$ (2:2:1 BPS:MMW:CM) showed statistically identical results of CEC where the numerically higher value was obtained from $\mathrm{T}_{2}$ treatment $\left(41.3 \mathrm{cmol} \mathrm{kg}^{-1}\right)$ and a lower value was found in the $\mathrm{T}_{4}$ treatment $\left(32.1 \mathrm{cmol} \mathrm{kg}^{-1}\right)$. In the final compost, CEC was higher by $45 \%$ than that of the initial condition.

\subsection{Changes in Macro- and Micro-Nutrients}

Co-composting of BPS, MMW, and CM in different ratios had varied nutrient concentrations in the final compost (Table 3). In the final compost, the highest values of $\mathrm{P}$ $\left(9.84 \mathrm{~g} \mathrm{~kg}^{-1}\right), \mathrm{Ca}\left(14.8 \mathrm{~g} \mathrm{~kg}^{-1}\right), \mathrm{Zn}\left(456 \mathrm{mg} \mathrm{kg}^{-1}\right), \mathrm{Cu}\left(60.7 \mathrm{mg} \mathrm{kg}^{-1}\right)$, and $\mathrm{Mn}\left(784 \mathrm{mg} \mathrm{kg}^{-1}\right)$ were recorded from the $\mathrm{T}_{2}$ pile having BPS, MMW, and CM at a 1:2:1 ratio but the highest values of $\mathrm{K}\left(12.1 \mathrm{~g} \mathrm{~kg}^{-1}\right), \mathrm{Mg}\left(5.94 \mathrm{~g} \mathrm{~kg}^{-1}\right), \mathrm{Na}\left(2.70 \mathrm{~g} \mathrm{~kg}^{-1}\right)$, and $\mathrm{S}\left(300 \mathrm{~g} \mathrm{~kg}^{-1}\right)$ were recorded in the $\mathrm{T}_{1}$ pile. This was comparable to the lowest value of all nutrients observed in the $\mathrm{T}_{4}$ compost, having a higher amount of BPS added (50\%). However, the concentrations of $\mathrm{P}, \mathrm{K}, \mathrm{Ca}, \mathrm{Na}$, and $\mathrm{Zn}$ were increased by $79.2 \%, 73.3 \%, 44.7 \%, 41.2 \%$, and $86.1 \%$, respectively, in the $\mathrm{T}_{2}$ pile. In contrast, the amounts of $\mathrm{K}, \mathrm{Mg}$, and $\mathrm{Na}$ in the $\mathrm{T}_{4}$ pile, having more BPS ( $50 \%$ ), fell by $7.08 \%, 8.56 \%$, and $1.87 \%$, respectively, compared to their corresponding initial value.

Table 3. Changes of total macro- and micronutrients of different treatments $\left(\mathrm{T}_{1}-\mathrm{T}_{6}\right)$ during the composting period.

\begin{tabular}{|c|c|c|c|c|c|c|c|c|c|}
\hline \multirow[b]{2}{*}{ Treatments } & \multicolumn{3}{|c|}{$P\left(g_{k g}^{-1}\right)$} & \multicolumn{3}{|c|}{$\mathrm{K}\left(\mathrm{g} \mathrm{kg}^{-1}\right)$} & \multicolumn{3}{|c|}{$\mathrm{Ca}\left(\mathrm{g} \mathrm{kg}^{-1}\right)$} \\
\hline & Initial & Final & $\%$ Increase & Initial & Final & $\%$ Increase & Initial & Final & $\%$ Increase \\
\hline $\mathrm{T}_{1}$ & $4.14 \pm 0.13 \mathrm{bc}$ & $6.76 \pm 0.27 b$ & 63.29 & $7.47 \pm 0.18 b$ & $12.1 \pm 0.47 \mathrm{a}$ & 61.98 & $6.64 \pm 0.26 b$ & $8.97 \pm 0.19 c$ & 35.09 \\
\hline $\mathrm{T}_{2}$ & $5.49 \pm 0.20 \mathrm{a}$ & $9.84 \pm 0.35 \mathrm{a}$ & 79.23 & $5.28 \pm 0.11 \mathrm{c}$ & $9.15 \pm 0.46 b$ & 73.30 & $10.23 \pm 0.23 \mathrm{a}$ & $14.8 \pm 0.17 \mathrm{a}$ & 44.67 \\
\hline $\mathrm{T}_{3}$ & $6.20 \pm 0.15 \mathrm{a}$ & $10.4 \pm 0.16 \mathrm{a}$ & 67.74 & $4.84 \pm 0.22 c$ & $8.04 \pm 0.42 b$ & 66.12 & $9.88 \pm 0.09 \mathrm{a}$ & $14.2 \pm 0.26 \mathrm{ab}$ & 43.72 \\
\hline $\mathrm{T}_{4}$ & $3.45 \pm 0.10 \mathrm{c}$ & $4.39 \pm 0.12 c$ & 27.25 & $10.6 \pm 0.12 \mathrm{a}$ & $9.85 \pm 0.35 \mathrm{ab}$ & -7.08 & $5.97 \pm 0.14 \mathrm{c}$ & $5.08 \pm 0.17 \mathrm{~d}$ & -14.90 \\
\hline $\mathrm{T}_{5}$ & $3.69 \pm 0.13 \mathrm{bc}$ & $6.64 \pm 0.26 b$ & 79.95 & $6.04 \pm 0.14 c$ & $9.26 \pm 0.25 b$ & 53.31 & $6.43 \pm 0.17 b$ & $8.46 \pm 0.20 c$ & 31.57 \\
\hline
\end{tabular}


Table 3. Cont.

\begin{tabular}{|c|c|c|c|c|c|c|c|c|c|}
\hline \multirow[b]{2}{*}{ Treatments } & \multicolumn{3}{|c|}{$P\left(\mathrm{~g} \mathrm{~kg}^{-1}\right)$} & \multicolumn{3}{|c|}{$\mathrm{K}\left(\mathrm{g} \mathrm{kg}^{-1}\right)$} & \multicolumn{3}{|c|}{$\mathrm{Ca}\left(\mathrm{g} \mathrm{kg}^{-1}\right)$} \\
\hline & Initial & Final & $\%$ Increase & Initial & Final & $\%$ Increase & Initial & Final & $\%$ Increase \\
\hline $\mathrm{T}_{6}$ & $4.39 \pm 0.17 b$ & $7.50 \pm 0.20 \mathrm{~b}$ & 70.84 & $5.81 \pm 0.17 c$ & $7.55 \pm 0.22 b$ & 29.95 & $9.18 \pm 0.19 a$ & $12.8 \pm 0.26 \mathrm{~b}$ & 39.43 \\
\hline \multirow[t]{2}{*}{ LSD (0.05) } & 0.84 & 1.19 & - & 1.32 & 2.41 & - & 1.28 & 1.65 & - \\
\hline & \multicolumn{3}{|c|}{$\mathrm{Mg}\left(\mathrm{g} \mathrm{kg}^{-1}\right)$} & \multicolumn{3}{|c|}{$\mathrm{Na}\left(\mathrm{g} \mathrm{kg}^{-1}\right)$} & \multicolumn{3}{|c|}{$\mathrm{S}\left(\mathrm{mg} \mathrm{kg}^{-1}\right)$} \\
\hline Treatments & Initial & Final & $\%$ Increase & Initial & Final & $\%$ Increase & Initial & Final & $\%$ Increase \\
\hline $\mathrm{T}_{1}$ & $3.77 \pm 0.11 b c$ & $5.94 \pm 0.03 \mathrm{a}$ & 57.56 & $2.05 \pm 0.02 b$ & $2.70 \pm 0.04 \mathrm{a}$ & 31.71 & $270 \pm 8.15 \mathrm{a}$ & $300 \pm 6.12 \mathrm{a}$ & 11.11 \\
\hline $\mathrm{T}_{2}$ & $3.45 \pm 0.02 c$ & $4.81 \pm 0.04 b$ & 39.42 & $1.70 \pm 0.02 \mathrm{~d}$ & $2.40 \pm 0.02 \mathrm{~b}$ & 41.18 & $200 \pm 4.89 \mathrm{~d}$ & $250 \pm 4.08 \mathrm{c}$ & 25.00 \\
\hline $\mathrm{T}_{3}$ & $3.38 \pm 0.07 c$ & $4.62 \pm 0.03 c$ & 36.69 & $1.81 \pm 0.01 \mathrm{c}$ & $2.31 \pm 0.03 c$ & 27.62 & $190 \pm 3.67 \mathrm{~d}$ & $270 \pm 8.16 \mathrm{bc}$ & 42.11 \\
\hline $\mathrm{T}_{4}$ & $4.51 \pm 0.16 \mathrm{a}$ & $4.12 \pm 0.04 \mathrm{~d}$ & -8.65 & $2.14 \pm 0.02 \mathrm{a}$ & $2.10 \pm 0.02 \mathrm{~d}$ & -1.87 & $230 \pm 5.30 \mathrm{bc}$ & $290 \pm 3.26 \mathrm{ab}$ & 26.09 \\
\hline $\mathrm{T}_{5}$ & $3.91 \pm 0.04 b$ & $4.86 \pm 0.03 b$ & 24.30 & $1.81 \pm 0.03 c$ & $2.30 \pm 0.03 \mathrm{c}$ & 27.07 & $250 \pm 4.89 \mathrm{ab}$ & $260 \pm 4.48 c$ & 4.00 \\
\hline $\mathrm{T}_{6}$ & $3.40 \pm 0.08 c$ & $4.59 \pm 0.03 c$ & 35.00 & $1.59 \pm 0.02 \mathrm{e}$ & $2.14 \pm 0.05 \mathrm{~d}$ & 34.59 & $210 \pm 4.08 \mathrm{~cd}$ & $250 \pm 2.85 c$ & 19.05 \\
\hline \multirow[t]{2}{*}{$\operatorname{LSD}(0.05)$} & 0.44 & 0.13 & - & 0.04 & 0.08 & - & 23.73 & 21.19 & - \\
\hline & \multicolumn{3}{|c|}{$\mathrm{Zn}\left(\mathrm{mg} \mathrm{kg}^{-1}\right)$} & \multicolumn{3}{|c|}{$\mathrm{Cu}\left(\mathrm{mg} \mathrm{kg}^{-1}\right)$} & \multicolumn{3}{|c|}{$\mathrm{Mn}\left(\mathrm{mg} \mathrm{kg}^{-1}\right)$} \\
\hline Treatments & Initial & Final & $\%$ Increase & Initial & Final & $\%$ Increase & Initial & Final & $\%$ Increase \\
\hline $\mathrm{T}_{1}$ & $170 \pm 3.26 \mathrm{~d}$ & $230 \pm 6.12 \mathrm{~d}$ & 35.3 & $31.3 \pm 1.02 \mathrm{ab}$ & $49.0 \pm 1.33 b$ & 56.5 & $\begin{array}{c}270 \pm 11.02 \\
\mathrm{~cd}\end{array}$ & $470 \pm 8.16 \mathrm{~d}$ & 74.1 \\
\hline $\mathrm{T}_{2}$ & $245 \pm 4.08 \mathrm{a}$ & $456 \pm 6.53 \mathrm{a}$ & 86.1 & $28.7 \pm 0.81 b$ & $60.7 \pm 1.17 \mathrm{a}$ & 111 & $\begin{array}{c}319 \pm 11.71 \\
a b\end{array}$ & $784 \pm 13.88 \mathrm{a}$ & 145.8 \\
\hline $\mathrm{T}_{3}$ & $241 \pm 4.10 \mathrm{ab}$ & $\begin{array}{c}426 \pm 6.53 \\
a b\end{array}$ & 76.8 & $21.4 \pm 0.57 \mathrm{c}$ & $59.6 \pm 1.06 \mathrm{a}$ & 178 & $255 \pm 6.12 \mathrm{~d}$ & $670 \pm 12.24 b$ & 162.7 \\
\hline $\mathrm{T}_{4}$ & $150 \pm 4.08 \mathrm{e}$ & $170 \pm 2.04 \mathrm{e}$ & 13.3 & $33.4 \pm 0.73 \mathrm{a}$ & $34.0 \pm 0.74 \mathrm{c}$ & 1.8 & $342 \pm 8.97 a$ & $370 \pm 6.12 \mathrm{e}$ & 8.2 \\
\hline $\mathrm{T}_{5}$ & $193 \pm 2.86 c$ & $310 \pm 8.16 c$ & 60.6 & $29.3 \pm 0.53 b$ & $51.3 \pm 0.69 b$ & 75.1 & $292 \pm 4.89 \mathrm{bc}$ & $583 \pm 8.87 c$ & 99.7 \\
\hline $\mathrm{T}_{6}$ & $224 \pm 4.49 \mathrm{~b}$ & $419 \pm 7.75 b$ & 87.1 & $22.3 \pm 0.93 \mathrm{c}$ & $47.7 \pm 0.37 \mathrm{~b}$ & 113.9 & $244 \pm 5.71 \mathrm{~d}$ & $602 \pm 12.23 c$ & 146.7 \\
\hline $\operatorname{LSD}(0.05)$ & 18.82 & 31.11 & - & 3.53 & 6.61 & - & 35.50 & 50.09 & - \\
\hline
\end{tabular}

Here, piles, viz., $\mathrm{T}_{1}=1: 1: 1, \mathrm{~T}_{2}=1: 2: 1, \mathrm{~T}_{3}=1: 3: 1, \mathrm{~T}_{4}=2: 1: 1, \mathrm{~T}_{5}=2: 2: 1$, and $\mathrm{T}_{6}=2: 3: 1$, indicate mixture ratio of BPS, MMW, and CM respectively. Mean \pm standard error within the column followed by the same letter are not statistically significant at $p \geq 0.05$ by LSD Test.

\subsection{Germination Index (\%) under the Compost}

The germination index showed a parallel or straight trend up to the 14th day in all piles except the $\mathrm{T}_{4}$ pile (with a higher amount of BPS), which experienced a slight decline up to the 19th day. In the study, the GI (\%) started to increase from 14-19 days in all piles $\left(\mathrm{T}_{1}-\mathrm{T}_{6}\right)$ towards the end of composting (Figure 7). The order of the GI values was 129, 125, $115,93.4,87.5$, and $72.4 \%$ in $\mathrm{T}_{2}, \mathrm{~T}_{3}, \mathrm{~T}_{6}, \mathrm{~T}_{5}, \mathrm{~T}_{1}$, and $\mathrm{T}_{4}$ piles, respectively. The maximum germination index $(129 \%)$ was recorded in $\mathrm{T}_{2}$ pile having a higher amount of MMW used, which was statistically similar to $\mathrm{T}_{3}(125 \%)$, while the $\mathrm{T}_{4}$ pile showed the lowest $72.4 \%$ from the final compost. 


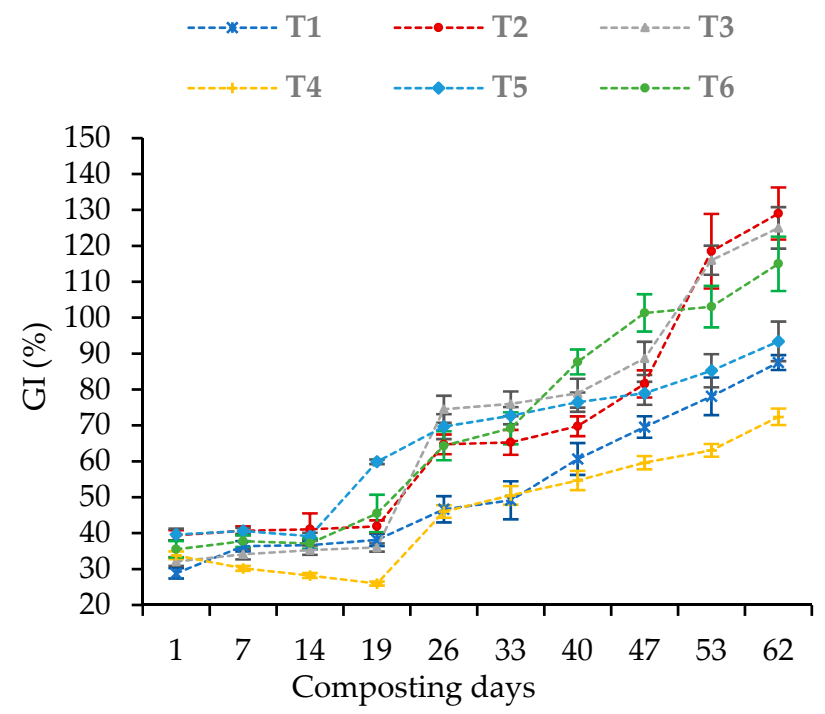

Figure 7. Changes of germination index in different treatments over the composting period. Each marker point represents mean $(n=3)$, and the vertical bars indicate Standard Error of Means (S.E.M). Legends: BPS, MMW, and CM mixed at $\mathrm{T}_{1}=1: 1: 1, \mathrm{~T}_{2}=1: 2: 1, \mathrm{~T}_{3}=1: 3: 1, \mathrm{~T}_{4}=2: 1: 1, \mathrm{~T}_{5}=2: 2: 1$, and $\mathrm{T}_{6}=2: 3: 1$, respectively.

\section{Discussion}

The final composts, which had banana pseudostem (BPS), mushroom media waste (MMW), and chicken manure (CM) at the ratios of 1:2:1 and 1:3:1, did better in compost production and germination of sweet corn seeds. Based on the physical and chemical changes recorded during the co-composting, it emerged that the compost piles having more MMW was transformed into a compost of good quality. These composts showed better maturity and stability based on the temperature, $\mathrm{C}: \mathrm{N}$ ratio, $\mathrm{CEC}$, weight loss $\left(\mathrm{CO}_{2}\right.$ evolution), nutrient concentration, and seed germination. These features are discussed in more detail below.

\subsection{Monitoring Temperature during the Composting}

Temperature during composting is an important indicator of its maturity and quality [42]. An ideal composting process consists of three phases of temperature, namely, the thermophilic $\left(>50{ }^{\circ} \mathrm{C}\right)$, mesophilic $\left(40-50{ }^{\circ} \mathrm{C}\right)$, and cooling phases $\left(<40^{\circ} \mathrm{C}\right)$, where the thermophilic stage represents the rapid decomposition of organic matter through microbial activity and the mesophilic and cooling phases may cause increased nitrous oxide emission [43]. The decline of the temperature below $40{ }^{\circ} \mathrm{C}$ expressed the maturity of compost [44]. In our study, the $\mathrm{T}_{2}$ pile showed a faster rise in temperature and longer thermophilic phase lasting up to 30 days followed by $\mathrm{T}_{3}$ due to the incorporation of $50 \%$ mushroom media waste (MMW) as a $\mathrm{C}$ source. The microbial degradation of added OM materials that released $\mathrm{CO}_{2}$ led to an increase in the compost temperature [45]. Some researchers even showed that two stage co-composting has double thermophilic stages indicating even faster decomposition and maturity of compost [44]. Throughout the whole process, $\mathrm{T}_{4}$ treatment did not reach the thermophilic stage due to the addition of a higher amount (50\%) of BPS while excess moisture was evident in BPS. However, the early drop in temperature by the 49 th day to cooling phase $\left(<40^{\circ} \mathrm{C}\right)$ indicated 13 days earlier maturity of the $\mathrm{T}_{2}$ compost compared to $\mathrm{T}_{4}$. The declining temperature also meant that the small portion of the easily degradable composting materials remained in the cooling phase [46].

\subsection{Changes in $\mathrm{pH}$ and $\mathrm{EC}$ during the Co-Composting}

The $\mathrm{pH}$ and $\mathrm{EC}$ are important parameters in composting, and they indicate the rate of decomposition of compost as well as the suitability of its application in soil. Overall, the compost piles resulted in an alkaline $\mathrm{pH}(\geq 10)$ and a higher EC value from 
2.38-3.71 dS m $\mathrm{m}^{-1}$ due to the use of alkaline materials rich in $\mathrm{K}$ and Ca (Table 1, Figure 3). During the initial stage (1-21 days), the $\mathrm{pH}$ showed an unchanged or slightly increasing trend. After 21 days of co-composting, the $\mathrm{pH}$ significantly increased with the decrease in the temperature, the mineralization of organic $\mathrm{N}$, and the release of $\mathrm{NH}_{4}$ ions. A similar trend was detected by Jolanun and Towprayoon [47]. In the present study, $\mathrm{T}_{2}$ (1:2:1) had the lowest value of $\mathrm{pH}$ (10.0) followed by the $\mathrm{T}_{3}$ (1:3:1) pile, which received $25 \% \mathrm{BPS}, 50 \%$ $\mathrm{MMW}$, and $25 \% \mathrm{CM}$ in the process (Figure 2). This outcome was consistent with the $\mathrm{pH}$ (9.3-9.7) of banana peel compost as studied by Kalemelawa et al. [15], who reported that high $\mathrm{K}$ concentrations in banana waste forms a strong base $(\mathrm{KOH})$ that increases the $\mathrm{pH}$ value. However, the $\mathrm{T}_{2}$ compost with moderately alkaline $\mathrm{pH}$ could be effective in diminishing the acidity of acidic soil. In addition, $\mathrm{T}_{1}(33.33 \% \mathrm{BPS})$ and $\mathrm{T}_{4}(50 \% \mathrm{BPS})$ piles were BPS-dominated composts which recorded higher EC values. The added BPS and/or $\mathrm{CM}$ contained a higher amount of $\mathrm{K}$ and Ca salts (Table 1), which increased the EC of the composts. The release of mineral salts due to volume loss via decomposition, increased the EC values studied by Silva and Brás [13]. Considering the individual EC of the piles, $\mathrm{T}_{2}$ resulted in the most suitable value of $2.38 \mathrm{dS} \mathrm{m}^{-1}$, followed by the acceptable limit of $\mathrm{EC}<3 \mathrm{dS} \mathrm{m}^{-1}$ [48]. Thus, the $\mathrm{T}_{2}$ compost having $25 \% \mathrm{BPS}, 50 \% \mathrm{MMW}$, and $25 \% \mathrm{CM}$ is suitable as an organic fertilizer.

\subsection{Changes in OM, TOC, C:N, and CEC during the Co-Composting}

Due to the long-term persistence of thermophilic temperatures, more organic matter is lost in the $\mathrm{T}_{2}$ pile (1:2:1 BPS:MMW:CM), resulting in a lower OM (36.1\%) content in the final compost (Figure 4). In this study, the $\mathrm{T}_{2}$ pile having a higher proportion $(50 \%)$ of MMW contained the various type of enzymes (results are included in another manuscript under review), and fungus mycelium [9], thereby resulting in 54.5\% of OM loss. This amount of reduction in $\mathrm{OM}$ in the present study is consistent with the reduction of $\mathrm{OM}$ $(47-52 \%)$ in the study conducted by Kulcu et al. [49]. A more than $42 \%$ reduction in OM was considered able to stabilize the process [16]. Fang et al. [9] also recorded the reduction of $\mathrm{OM}$ in the mushroom substrate composting material. Moreover, the addition of a higher proportion of MMW with lower BPS may create a favorable microbial environment through better aeration in the composting and facilitate the faster degradation of OM [42]. On the other hand, the $\mathrm{T}_{1}$ (33.3\% BPS, 33.3\% MMW, and 33.3\% CM) and $\mathrm{T}_{4}(50 \% \mathrm{BPS}, 25 \%$ MMW, and 25\% CM) piles were recorded with the higher OM content in the final compost than the $\mathrm{T}_{2}$ pile. It strongly suggests that those piles were partially decomposed due to a limitation in microbial activity or higher moisture content (72 to $79 \%$ ). In addition, the existing lignin and cellulose in banana pseudostem [32] were slowly degraded and persisted for a longer period of time, thus confirming higher OM contents in the $T_{1}$ and $\mathrm{T}_{4}$ piles.

In the composting process, the $\mathrm{C}$ content promotes the degradation of OM. A low $\mathrm{C}$ concentration can restrict biomass formation and compromise degradation [16]. The greater reduction of total organic carbon (TOC) content in $\mathrm{T}_{2}(53.8 \%)$ and $\mathrm{T}_{3}(52.8 \%)$ piles (Table 2$)$ indicated the higher bio-oxidation of OM maintained by the thermophilic temperature (Figure 1a). In this study, the reduction of the C:N ratio is mainly due to the decomposition of organic matter (loss of $\mathrm{C}$ as $\mathrm{CO}_{2}$ via transformation). In the course of decomposition during composting, the increase of the total $\mathrm{N} \%$ was associated with the volume reduction. The increase in inorganic $\mathrm{N}$ in the $\mathrm{T}_{2}$ co-compost pile (having higher $\mathrm{MMW}$ ) may contribute to the total $\mathrm{N}$ increase as well as the low $\mathrm{C}: \mathrm{N}$ ratio. The strong sorption capacity of the added MMW bulk material may also help adsorb $\mathrm{N}$ on its large surface area. The highest reduction of $\mathrm{C}(53.8 \%)$ through OM decomposition was also associated with the low C:N ratio (12.4) (Table 2). These outcomes reflect the result of composting of wood chips with green waste as documented elsewhere [18]. The compost with a $<20$ C:N ratio is more acceptable as noted by Gaind [35].

On the other hand, as the BPS had lower C content, even under high moisture (79.3\%) content in it, the OM decomposition and loss of $\mathrm{C}$ did slow down (Figure 4 and Table 2). 
The higher $\mathrm{C}: \mathrm{N}$ ratio (23.3) in the $\mathrm{T}_{4}$ compost (2:1:1 BPS:MMW:CM) is associated with these. The $\mathrm{N}$ loss through volatilization might also affect the low $\mathrm{C}: \mathrm{N}$ ratio obtained in the final compost. The results are consistent with Mohee et al. [48] who discovered that microbial consumption of $\mathrm{C}$ decreased the $\mathrm{C}: \mathrm{N}$ ratio of the compost. In the present study, the CEC was increased in all treatments from the initial to final compost (Table 2), and it varied from treatment to treatment and with the amount of added banana pseudostem and mushroom media waste. The CEC was greater of those treatments due to higher decomposition of added banana pseudostem and mushroom media waste, particularly in the $\mathrm{T}_{2}$ compost. This may explain the high content of exchangeable cations in BPS and MMW (Table 1).

Zhang and Sun [18] obtained a 45\% increase in CEC from the co-composting of wood chips and green waste compared to green waste that was similar to the $\mathrm{T}_{2}$ compost. Bahtiar et al. [7] studied banana waste as a vital source of $\mathrm{Na}, \mathrm{K}, \mathrm{Ca}$, and $\mathrm{Mg}$ as possibly increasing the CEC in compost. Moreover, the carboxyl and phenolic functional groups may emerge from the humification of organic materials which can increase the CEC in $\mathrm{T}_{2}$ compost. This finding appeared to agree with what Steiner et al. [50] found. The greater CEC value also represents the higher decomposition rate and nutrient retention capacity of compost [50]. Although the $\mathrm{T}_{4}(2: 1: 1$ of BPS, MMW, and CM) compost contained BPS in greater amounts, the CEC was comparatively lower than that of $\mathrm{T}_{1}(1: 1: 1)$ and $\mathrm{T}_{2}(1: 2: 1)$ compost. However, at the initial stage, the addition of $50 \%$ BPS in the $\mathrm{T}_{4}$ treatment may lead to having excess moisture that ultimately leached down some cations and lowered the CEC value (Table 3).

\subsection{Changes in TN and Inorganic $N$ during the Co-Composting}

The stimulated microbial activity under high temperature and alkaline $\mathrm{pH}$ degrades the organic compounds and might induce ammonia volatilization and reduced TN in the pile having an increased amount of MMW ( $\mathrm{T}_{2}$ pile). The loss of $\mathrm{TN} 11.1 \%$ was much lower than that of TN loss $21-40 \%$ from the co-composting of biowaste and sugarcane filter cake [16]. Composts with 1-2\% $\mathrm{N}$ have minimal effect on $\mathrm{N}$ fertilizer requirements for crop production [51]. However, $\mathrm{TN}$ in $\mathrm{T}_{2}(1.53 \%)$ compost remained within this range for agricultural use. In addition, the $\mathrm{T}_{2}$ pile receiving a higher proportion of $\mathrm{MMW}$, which could assimilate $\mathrm{NH}_{3}$ on its large surface and in turn contribute $\mathrm{NO}_{3}-\mathrm{N}$ [18] as well as TN. A similar finding was noted by Guo et al. [39]. Most of the inorganic N remained in the form of $\mathrm{NH}_{4}-\mathrm{N}$ and low levels of $\mathrm{NO}_{3}-\mathrm{N}$ were detected in the compost.

During the composting, a reverse trend of $\mathrm{NH}_{4}-\mathrm{N}$ and $\mathrm{NO}_{3}-\mathrm{N}$ production was evident in all the piles followed by a typical composting process [52]. A similar trend was observed by Kalemelawa et al. [15] from banana peel compost. In the final stage, $\mathrm{T}_{2}$ showed a significantly $(p<0.05)$ higher value $\left(179 \mathrm{mg} \mathrm{kg}^{-1}\right)$ of $\mathrm{NH}_{4}-\mathrm{N}$ over the other piles, which increased $\mathrm{NH}_{4}-\mathrm{N}$ by $28.5 \%$ from the initial value $\left(140 \mathrm{mg} \mathrm{kg}^{-1}\right.$ ) due to the decomposition of organic compounds (Figure 5). This increase in $\mathrm{NH}_{4}-\mathrm{N}$ was due to the degradation of protein and amino acid by $\mathrm{NH}_{4}{ }^{+}$ions [53]. After 14 days, $\mathrm{NH}_{4}-\mathrm{N}$ decreased with the volatilization of $\mathrm{NH}_{3}$ due to high temperature $\left(>40{ }^{\circ} \mathrm{C}\right)$ and high alkaline $\mathrm{pH}(10)$ as mentioned by Meng et al. [46]. Furthermore, the fall in temperature may have activated the nitrifying bacteria for nitrification [54], which might be attributed to the highest $\mathrm{NO}_{3}-\mathrm{N}$ (51.9 $\mathrm{mg} \mathrm{kg}^{-1}$ ) in the $\mathrm{T}_{2}$ compost at the final stage. On the other hand, excess moisture from BPS may inactivate nitrifying bacteria that can affect the $\mathrm{NO}_{3}-\mathrm{N}$ production in the $\mathrm{T}_{4}$ pile where increasing use of BPS was evident.

\subsection{Changes in Nutrients Density during the Co-Composting}

The content of macronutrients is a very important variable of compost [51]. Macro and micronutrients in the final compost were significantly $(p<0.05)$ influenced by the amount of BPS and MMW in the composting process (Table 3$)$. Results indicated that the $\mathrm{T}_{2}(25 \%$ BPS with 50\% MMW) compost increased the highest percentages of nutrient concentrations ( $P$ $79.23 \%$, K 73.30\%, Ca $44.67 \%$, Na $41.18 \%$, and $\mathrm{Zn} 86.10 \%$ ) followed by $\mathrm{T}_{3}$ from the initial to final compost (Table 3 ) compared to other piles. It was due to the complete decomposition 
of OM through a longer thermophilic phase [55] (Figure 1a,b). These results agreed with the findings of Kalemelawa et al. [15], who observed the increase in P (86\%) and K (34\%) in banana peel with cow dung compost. Ultra et al. [56] detected extremely large amounts of $\mathrm{K}, \mathrm{Ca} \mathrm{Mg}$, and $\mathrm{Na}$ in banana waste compost. Moreover, the $\mathrm{T}_{2}$ and $\mathrm{T}_{3}$ composts resulted in extremely large amounts of $\mathrm{Zn}, \mathrm{Cu}$, and $\mathrm{Mn}$ through the humification of the added BPS and MMW. These outcomes were similar to Chimuka and Manungufala [57], who suggested that $\mathrm{Cu}$ and $\mathrm{Zn}$ have a strong affinity to adsorb with organic and carbonate fractions in compost. In another study, Hsu and Lo [58] indicated that decomposition of $\mathrm{OM}$ increased the amount of $\mathrm{Cu}, \mathrm{Mn}, \mathrm{Zn}$ in compost by almost two- to threefold, which resulted in a greatly improved compost product. On the other hand, the $\mathrm{T}_{4}$ pile, which received $50 \%$ BPS, showed the incomplete decomposition of OM due to the limitation of C (34.55\%) and excess moisture (Table 2). The excess moisture (79\%) from BPS created a poor window system and microbial inactivity for OM degradation [39]. Moreover, excess moisture in $\mathrm{T}_{4}(50 \% \mathrm{BPS})$ compost influenced leaching loss of $\mathrm{K}(7.08 \%), \mathrm{Ca}(14.90 \%), \mathrm{Mg}$ $(8.56 \%)$, and $\mathrm{Na}(1.87 \%)$, so the value of the final content was lower than that of the initial one. This is despite the banana pseudostem being rich in cations [59]. Thus, the $\mathrm{T}_{1}$ and $\mathrm{T}_{5}$ piles showed a higher increment of $\mathrm{K}, \mathrm{Mg}$, and $\mathrm{Na}$ in the final product. However, all the nutrients in the $\mathrm{T}_{2}$ compost (1:2:1 i.e., 25\% BPS, 50\% MMW, and 25\% CM) can be potential sources of organic fertilizer for crop production and especially for low $\mathrm{pH}$ soil.

\subsection{Changes in Germination Index during the Co-Composting}

The seed germination test is the most sensitive indicator for evaluating the phytotoxicity and maturity of compost [60]. This study showed that the GI declined or remained unchanged in the initial stage, and it may have been due to the formation of organic acids or salts at a high temperature, prevailing up to 19 days in the compost pile. This result is consistent with the findings of Guo et al. [39]. After 19 days, GI started to increase in all piles mainly due to the degradation of toxic substances [61] throughout the study period. In the final stage of composting, all the compost piles with varied feedstock ratios $\left(\mathrm{T}_{1}-\mathrm{T}_{3}\right)$ and $\left(\mathrm{T}_{5}-\mathrm{T}_{6}\right)$ showed a GI value above $80 \%$, except $\mathrm{T}_{4}$, which documented higher BPS. $\mathrm{T}_{2}$ and $\mathrm{T}_{3}$ resulted in higher GI values of $129 \%$ and $125 \%$, respectively, with the addition of $20-25 \%$ of BPS in the composting. The higher GI might be attributed to their maturity and being free of toxic substances or less toxic to germination of seedlings, as found by Zorpas and Loizidou [62]. The GI value showed $<80 \%$ in the $\mathrm{T}_{4}$ pile, which means that the BPS might not have been decomposed properly, excessive salts were present in it, and/or toxic substances were added from the higher amount of BPS (2:1:1 of BPS:MMW:CM) to the process. In short, $20-25 \%$ of BPS with 50-60\% MMW had higher seed germination that can be safe for application in agricultural soil.

\section{Conclusions}

The present study examined the optimal ratio of banana pseudostem, mushroom media waste, and chicken manure for the composting process, which was monitored in connections with temperature, $\mathrm{pH}, \mathrm{EC}, \mathrm{OM}, \mathrm{TOC}, \mathrm{C}: \mathrm{N}$ ratio, CEC, TN, and other nutrients as a function of time. Around half the proportion of BPS to MMW enhanced composting process by extending the duration of thermophilic phase; improved the $\mathrm{pH}$, EC, CEC values; and increased the macro- and micronutrient concentrations. Of the six combinations of feedstocks, the addition of BPS, MMW, and CM at a 1:2:1 ratio (25\% BPS, $50 \% \mathrm{MMW}, 25 \% \mathrm{CM}$ ) decomposed earlier and performed better in terms of acceptable $\mathrm{pH}$ value (10), suitable C:N ratio $(<15)$, nutrients content and showed no toxicity to crops. That is why the optimal seed germination was associated with the improved compost properties. The highly alkaline $\mathrm{pH}$ of the compost samples suggests that it could be employed for the upgradation of acidic soils. However, the effectiveness of these alkaline composts has yet not been tested in the field level. Thus, the next research would be forwarded to using this compost in a soil-plant system in acidic soil, especially Ultisols and Oxisols. 
Author Contributions: Conceptualization, M.S.I. and S.K.; methodology, M.S.I. and M.A.H.; formal analysis, M.S.I., S.K., and M.A.H.; investigation, M.S.I. and S.K.; resources, M.S.I.; data curation, M.S.I., A.M.A., T.G.H., and K.M.A.; writing—original draft preparation, M.S.I.; writing-review and editing, S.K., T.G.H., and K.M.A.; visualization, M.S.I.; supervision, S.K. and K.M.A. All authors have read and agreed to the published version of the manuscript.

Funding: This research was funded by National Agricultural Technology Program-Phase 2 project (NATP-2), Bangladesh Agricultural Research Council (BARC), Farmgate, Dhaka-1215, Bangladesh.

Institutional Review Board Statement: Ethical review and approval were waived for this study, due to no obligatory rules existed for having Institutional Review Board Statement.

Informed Consent Statement: Not applicable.

Data Availability Statement: Data is not publicly available, though the data may be made available on request from the corresponding author.

Acknowledgments: The authors would like to express his gratitude to the authority of the National Agricultural Technology Programme, the Bangladesh Agricultural Research Council, and the Bangladesh Agricultural Research Institute for providing fellowship to perform research at the Faculty of Agriculture, Universiti Putra Malaysia. All faculty members and staff of the Department of Land Management are highly acknowledged because of their continuous technical support and cooperation in order to complete the research.

Conflicts of Interest: The authors declare no conflict of interest.

\section{References}

1. Bonoli, A.; Zanni, S.; Awere, E. Organic waste composting and sustainability in low-income communities in Palestine: Lessons from a pilot project in the village of Al Jalameh, Jenin. Int. J. Recycl. Org. Waste Agric. 2019, 8, 253-262. [CrossRef]

2. Wang, X.; Chen, L.; Xia, S.; Zhao, J. Changes of $\mathrm{Cu}, \mathrm{Zn}$, and Ni chemical speciation in sewage sludge co-composted with sodium sulfide and lime. J. Environ. Sci. 2008, 20, 156-160. [CrossRef]

3. Petric, I.; Helić, A.; Avdić, E.A. Evolution of process parameters and determination of kinetics for co-composting of organic fraction of municipal solid waste with poultry manure. Bioresour. Technol. 2012, 117, 107-116. [CrossRef]

4. Yu, H.; Xie, B.; Khan, R.; Shen, G. The changes in carbon, nitrogen components and humic substances during organic-inorganic aerobic co-composting. Bioresour. Technol. 2019, 271, 228-235. [CrossRef]

5. Sharma, M.; Patel, S.N.; Sangwan, R.S.; Singh, S.P. Biotransformation of banana pseudostem extract into a functional juice containing value added biomolecules of potential health benefits. Indian J. Exp. Biol. 2017, 55, 453-462.

6. FAO. FAOSTAT [WWW Document]. 2017. Available online: http://www.fao.org/faostat/en/\#data/QC (accessed on 31 January 2017).

7. Bahtiar, S.A.; Muayyad, A.; Ulfaningtias, L.; Anggara, J.; Priscilla, C.; Miswar, M. Compost use banana weevil (Musa Acuminata) to boost growth and content of sugar sweet corn (Zea mays L. Saccharata). J. Agric. Sci. 2017, 14, $18-22$.

8. Medina, E.; Paredes, C.; Pérez-Murcia, M.D.; Bustamante, M.A.; Moral, R. Spent mushroom substrates as component of growing media for germination and growth of horticultural plants. Bioresour. Technol. 2009, 100, 4227-4232. [CrossRef]

9. Fang, W.; Zhang, P.; Gou, X.; Zhang, H.; Wu, Y.; Ye, J.; Zeng, G. Volatile fatty acid production from spent mushroom compost: Effect of total solid content. Int. Biodeterior. Biodegrad. 2016, 113, 217-221. [CrossRef]

10. Blazy, V.; De Guardia, A.; Benoist, J.C.; Daumoin, M.; Lemasle, M.; Wolbert, D.; Barrington, S. Odorous gaseous emissions as influence by process condition for the forced aeration composting of pig slaughterhouse sludge. Waste Manag. 2014, 34, 1125-1138. [CrossRef]

11. Preusch, P.L.; Adler, P.R.; Sikora, L.J.; Tworkoski, T.J. Nitrogen and Phosphorus Availability in Composted and Uncomposted Poultry Litter. J. Environ. Qual. 2002, 31, 2051-2057. [CrossRef]

12. Hepperly, P.; Lotter, D.; Ulsh, C.Z.; Seidel, R.; Reider, C. Compost, Manure and Synthetic Fertilizer Influences Crop Yields, Soil Properties, Nitrate Leaching and Crop Nutrient Content Paul. Compost Sci. Util. 2009, 17, 117-126. [CrossRef]

13. Silva, M.E.; Brás, I. Co-Composting of Poultry Manure with Different Organic Amendments. Int. J. Environ. Ecol. Eng. 2016, 10, 848-852.

14. Bilba, K.; Arsene, M.A.; Ouensanga, A. Study of banana and coconut fibers. Botanical composition, thermal degradation and textural observations. Bioresour. Technol. 2007, 98, 58-68. [CrossRef] [PubMed]

15. Kalemelawa, F.; Nishihara, E.; Endo, T.; Ahmad, Z.; Yeasmin, R.; Tenywa, M.M.; Yamamoto, S. An evaluation of aerobic and anaerobic composting of banana peels treated with different inoculums for soil nutrient replenishment. Bioresour. Technol. 2012, 126, 375-382. [CrossRef] [PubMed]

16. Soto-Paz, J.; Oviedo-Ocaña, E.R.; Manyoma, P.C.; Marmolejo-Rebellón, L.F.; Torres-Lozada, P.; Barrena, R.; Sánchez, A.; Komilis, D. Influence of mixing ratio and turning frequency on the co-composting of biowaste with sugarcane filter cake: A mixture experimental design. Waste Biomass Valorization 2020, 11, 2475-2489. [CrossRef] 
17. Meunchang, S.; Panichsakpatana, S.; Weaver, R.W. Co-composting of filter cake and bagasse; by-products from a sugar mill. Bioresour. Technol. 2005, 96, 437-442. [CrossRef]

18. Zhang, L.; Sun, X. Influence of bulking agents on physical, chemical, and microbiological properties during the two-stage composting of green waste. Waste Manag. 2016, 48, 115-126. [CrossRef]

19. Nakasaki, K.; Nagasaki, K.; Ariga, O. Degradation of fats during thermophilic composting of organic waste. Waste Manag. Res. 2004, 22, 276-282. [CrossRef]

20. Francou, C.; Linères, M.; Derenne, S.; Le Villio-Poitrenaud, M.; Houot, S. Influence of green waste, biowaste and paper-cardboard initial ratios on organic matter transformations during composting. Bioresour. Technol. 2008, 99, 8926-8934. [CrossRef]

21. Vandecasteele, B.; Reubens, B.; Willekens, K.; De Neve, S. Composting for increasing the fertilizer value of chicken manure: Effects of feedstock on P availability. Waste Biomass Valorization 2014, 5, 491-503. [CrossRef]

22. Petric, I.; Selimbašić, V. Composting of poultry manure and wheat straw in a closed reactor: Optimum mixture ratio and evolution of parameters. Biodegradation 2008, 19, 53-63. [CrossRef]

23. Wang, P.; Changa, C.M.; Watson, M.E.; Dick, W.A.; Chen, Y.; Hoitink, H.A.J. Maturity indices for composted dairy and pig manures. Soil Biol. Biochem. 2004, 36, 767-776. [CrossRef]

24. Paredes, C.; Roig, A.; Bernal, M.P.; Sánchez-Monedero, M.A.; Cegarra, J. Evolution of organic matter and nitrogen during co-composting of olive mill wastewater with solid organic wastes. Biol. Fertil. Soils 2000, 32, 222-227. [CrossRef]

25. Ahn, H.K.; Richard, T.L.; Glanville, T.D. Laboratory determination of compost physical parameters for modeling of airflow characteristics. Waste Manag. 2008, 28, 660-670. [CrossRef] [PubMed]

26. Huang, G.F.; Wong, J.W.C.; Wu, Q.T.; Nagar, B.B. Effect of $\mathrm{C} / \mathrm{N}$ on composting of pig manure with sawdust. Waste Manag. 2004, 24, 805-813. [CrossRef]

27. Khan, S.; Chao, C.; Waqas, M.; Arp, H.P.H.; Zhu, Y.G. Sewage sludge biochar influence upon rice (Oryza sativa L) yield, metal bioaccumulation and greenhouse gas emissions from acidic paddy soil. Environ. Sci. Technol. 2013, 47, 8624-8632. [CrossRef] [PubMed]

28. Petric, I.; Mustafić, N. Dynamic modeling the composting process of the mixture of poultry manure and wheat straw. J. Environ. Manage. 2015, 161, 392-401. [CrossRef]

29. He, X.; Yin, H.; Han, L.; Cui, R.; Fang, C.; Huang, G. Effects of biochar size and type on gaseous emissions during pig manure/wheat straw aerobic composting: Insights into multivariate-microscale characterization and microbial mechanism. Bioresour. Technol. 2019, 271, 375-382. [CrossRef]

30. Kumar, R.; Verma, D.; Singh, B.L.; Kumar, U.; Shweta. Composting of sugar-cane waste by-products through treatment with microorganisms and subsequent vermicomposting. Bioresour. Technol. 2010, 101, 6707-6711. [CrossRef]

31. Czekała, W.; Malińska, K.; Cáceres, R.; Janczak, D.; Dach, J.; Lewicki, A. Co-composting of poultry manure mixtures amended with biochar-The effect of biochar on temperature and C- $\mathrm{CO}_{2}$ emission. Bioresour. Technol. 2016, 200, 921-927. [CrossRef]

32. Oliveira, L.; Cordeiro, N.; Evtuguin, D.V.; Torres, I.C.; Silvestre, A.J.D. Chemical composition of different morphological parts from "Dwarf Cavendish" banana plant and their potential as a non-wood renewable source of natural products. Ind. Crops Prod. 2007, 26, 163-172. [CrossRef]

33. Onwosi, C.O.; Igbokwe, V.C.; Odimba, J.N.; Eke, I.E.; Nwankwoala, M.O.; Iroh, I.N.; Ezeogu, L.I. Composting technology in waste stabilization: On the methods, challenges and future prospects. J. Environ. Manage. 2017, 190, 140-157. [CrossRef]

34. Krishnan, Y.; Bong, C.P.C.; Azman, N.F.; Zakaria, Z.; Othman, N.; Abdullah, N.; Ho, C.S.; Lee, C.T.; Hansen, S.B.; Hara, H. Co-composting of palm empty fruit bunch and palm oil mill effluent: Microbial diversity and potential mitigation of greenhouse gas emission. J. Clean. Prod. 2017, 146, 94-100. [CrossRef]

35. Gaind, S. Effect of fungal consortium and animal manure amendments on phosphorus fractions of paddy-straw compost. Int. Biodeterior. Biodegrad. 2014, 94, 90-97. [CrossRef]

36. Tiquia, S.M.; Richard, T.L.; Honeyman, M.S. Effect of windrow turning and seasonal temperatures on composting of hog manure from hoop structures. Environ. Technol. 2000, 21, 1037-1046. [CrossRef]

37. Cottenie, A. Soil testing and plant testing as a basis of fertilizer recommendation. FAO Soils Bull. 1980, 38, 70-73.

38. Keeney, D.R.; Nelson, D.W. Nitrogen inorganic forms. In Methods of Soil Analysis Part 2; Page, A.L., Keeney, D.R., Baker, D.E., Miller, R.H., Ellis, R.J., Eds.; Agron. Monogr 9. ASA and SSSA: Madison, WI, USA, 1982; pp. 159-165.

39. Guo, R.; Li, G.; Jiang, T.; Schuchardt, F.; Chen, T.; Zhao, Y.; Shen, Y. Effect of aeration rate, C/N ratio and moisture content on the stability and maturity of compost. Bioresour. Technol. 2012, 112, 171-178. [CrossRef] [PubMed]

40. Mirmostafaee, S.; Azizi, M.; Fujii, Y. Study of allelopathic interaction of essential oils from medicinal and aromatic plants on seed germination and seedling growth of lettuce. Agronomy 2020, 10, 163. [CrossRef]

41. SAS. SAS Statistical Software; Release 9.4; SAS Institute: Cary, NC, USA, 2008.

42. Zhang, L.; Sun, X. Changes in physical, chemical, and microbiological properties during the two-stage co-composting of green waste with spent mushroom compost and biochar. Bioresour. Technol. 2014, 171, 274-284. [CrossRef]

43. Li, R.; Wang, J.J.; Zhang, Z.; Shen, F.; Zhang, G.; Qin, R.; Li, X.; Xiao, R. Nutrient transformations during composting of pig manure with bentonite. Bioresour. Technol. 2012, 121, 362-368. [CrossRef]

44. Awasthi, M.K.; Pandey, A.K.; Bundela, P.S.; Wong, J.W.C.; Li, R.; Zhang, Z. Co-composting of gelatin industry sludge combined with organic fraction of municipal solid waste and poultry waste employing zeolite mixed with enriched nitrifying bacterial consortium. Bioresour. Technol. 2016, 213, 181-189. [CrossRef] 
45. Luo, W.H.; Yuan, J.; Luo, Y.M.; Li, G.X.; Nghiem, L.D.; Price, W.E. Effects of mixing and covering with mature compost on gaseous emissions during composting. Chemosphere 2014, 117, 14-19. [CrossRef]

46. Meng, L.; Li, W.; Zhang, S.; Wu, C.; Lv, L. Feasibility of co-composting of sewage sludge, spent mushroom substrate and wheat straw. Bioresour. Technol. 2017, 226, 39-45. [CrossRef]

47. Jolanun, B.; Towprayoon, S. Novel bulking agent from clay residue for food waste composting. Bioresour. Technol. 2010, 101, 4484-4490. [CrossRef]

48. Mohee, R.; Boojhawon, A.; Sewhoo, B.; Rungasamy, S.; Somaroo, G.D.; Mudhoo, A. Assessing the potential of coal ash and bagasse ash as inorganic amendments during composting of municipal solid wastes. J. Environ. Manage. 2015, 159, 209-217. [CrossRef]

49. Kulcu, R.; Sönmez, I.; Yaldiz, O.; Kaplan, M. Composting of spent mushroom compost, carnation wastes, chicken and cattle manures. Bioresour. Technol. 2008, 99, 8259-8264. [CrossRef] [PubMed]

50. Steiner, C.; Das, K.C.; Melear, N.; Lakly, D. Reducing Nitrogen Loss during Poultry Litter Composting Using Biochar. J. Environ. Qual. 2010, 39, 1236-1242. [CrossRef] [PubMed]

51. Sullivan, D.M.; Bary, A.I.; Miller, R.O.; Brewer, L.J. Interpreting Compost Analyses; Oregon State University Extension Service: Corvallis, OR, USA, 2018; pp. 1-10.

52. Tiquia, S.M.; Tam, N.F.Y. Fate of nitrogen during composting of chicken litter. Environ. Pollut. 2000, 110, 535-541. [CrossRef]

53. Hu, W.; Zheng, G.; Fang, D.; Cui, C.; Liang, J.; Zhou, L. Bioleached sludge composting drastically reducing ammonia volatilization as well as decreasing bulking agent dosage and improving compost quality: A case study. Waste Manag. 2015, 44, 55-62. [CrossRef] [PubMed]

54. Tiquia, S.M. Evolution of extracellular enzyme activities during manure composting. J. Appl. Microbiol. 2002, 92, 764-775. [CrossRef] [PubMed]

55. Li, R.; Wang, Q.; Zhang, Z.; Zhang, G.; Li, Z.; Wang, L.; Zheng, J. Nutrient transformation during aerobic composting of pig manure with biochar prepared at different temperatures. Environ. Technol. 2015, 36, 815-826. [CrossRef]

56. Ultra, V.U.; Mendoza, D.M.; Briones, A.M. Chemical changes under aerobic composting and nutrient supplying potential of banana residue compost. Renew. Agric. Food Syst. 2005, 20, 113-125. [CrossRef]

57. Chimuka, L.; Manungufala, T.E. Sources, Bioavailability and Fate of Heavy Metals and Organic Contaminants in Compost Manure. Dyn. Soil Dyn. Plant 2009, 3, 32-38.

58. Hsu, J.H.; Lo, S.L. Effect of composting on characterization and leaching of copper, manganese, and zinc from swine manure. Environ. Pollut. 2001, 114, 119-127. [CrossRef]

59. Ho, L.H.; Noor Aziah, A.A.; Bhat, R. Mineral composition and pasting properties of banana pseudo-stem flour from Musa acuminata x balbisiana cv. Awak grown locally in Perak, Malaysia. Int. Food Res. J. 2012, 19, 1479-1485. [CrossRef]

60. Luo, Y.; Liang, J.; Zeng, G.; Chen, M.; Mo, D.; Li, G.; Zhang, D. Seed germination test for toxicity evaluation of compost: Its roles, problems and prospects. Waste Manag. 2018, 71, 109-114. [CrossRef]

61. Yang, F.; Li, G.X.; Yang, Q.Y.; Luo, W.H. Effect of bulking agents on maturity and gaseous emissions during kitchen waste composting. Chemosphere 2013, 93, 1393-1399. [CrossRef]

62. Zorpas, A.A.; Loizidou, M. Sawdust and natural zeolite as a bulking agent for improving quality of a composting product from anaerobically stabilized sewage sludge. Bioresour. Technol. 2008, 99, 7545-7552. [CrossRef] 